\title{
Ecological considerations for species distribution modelling of euphausiids in the Northeast Pacific Ocean
}

\author{
Rhian Evans, Stéphane Gauthier, and Clifford L.K. Robinson
}

\begin{abstract}
Euphausiids are a keystone species in marine food webs of the Northeast Pacific Ocean, important for forage fish, commercial fish species and marine predators such as seabirds and whales. Ecosystem-based fisheries management relies on realistic lower-trophic-level information for forecasting under future changing climate scenarios. We synthesised information from quantitative modelling studies analysing the relationship between euphausiids and their environment for two species of euphausiids that dominate assemblages in this region - Euphausia pacifica and Thysanoessa spinifera. Studies analysed suggest that variables reflecting the physical and biological environment in situ, features reflecting the geomorphic marine landscape, and large-scale climate indices all significantly affect euphausiid biomass and distribution. Temperature was the most tested predictor variable in the euphausiid models reviewed; however, it was significant in fewer models than other variables tested. We review and compare model structures, predictor variable selection and temporal lag phases to develop recommendations for species distribution modelling of euphausiids in the Northeast Pacific Ocean. We believe the results from this review will be applicable globally across regions with similar climates where euphausiids are numerous and can be adapted for different species and environments.
\end{abstract}

Résumé : Les euphausiacés sont des espèces clés dans les réseaux trophiques marins du nord-est de l'océan Pacifique, d'importance pour des poissons-fourrages, des espèces commerciales de poissons et des prédateurs marins, dont des oiseaux marins et des baleines. La gestion écosystémique des pêches requiert de l'information sur les niveaux trophiques inférieurs pour établir des prévisions associées à des scénarios de changements climatiques futurs. Nous présentons une synthèse de l'information issue d'études de modélisation quantitatives de la relation entre les euphausiacés et leur milieu dans le nord-est du Pacifique pour deux espèces d'euphausiacés dominants dans les assemblages - Euphausia pacifica et Thysanoessa spinifera. Les études analysées indiqueraient que des variables qui reflètent le milieu physique et biologique en place, des caractéristiques du paysage géomorphologique marin et des indices climatiques à grande échelle ont tous une incidence significative sur la biomasse et la répartition des euphausiacés. Si la température est la variable prédictive la plus souvent analysée dans les modèles d'euphausiacés examinés, elle s'avère toutefois significative dans un moins grand nombre de modèles que d'autres variables analysées. Nous passons en revue et comparons les structures de modèles, la sélection de variables prédictives et les phases de décalage temporel afin de formuler des recommandations pour la modélisation de la répartition d'espèces d'euphausiacés dans le nord-est de l'océan Pacifique. Nous croyons que les résultats de la présente synthèse pourront être appliqués dans différentes régions du monde aux climats semblables où les euphausiacés sont nombreux et qu'ils peuvent être adaptés aux conditions océanographiques propres à différentes espèces. [Traduit par la Rédaction]

\section{Introduction}

Coastal seas are regions of rich biomass and high biodiversity. Active management of marine resources is often concentrated around the coast where anthropogenic and economic needs most often overlap with ecological and conservation priorities (Douvere and Ehler 2009). Marine spatial planning and ocean zoning is a tool used as part of Ecosystem Based Management (EBM) to manage multiple users of a marine space sustainably (Douvere 2008). A critical first step is to map biophysical patterns within geographical focal areas (Lourie and Vincent 2004; Crowder and Norse 2008), which requires difficult to obtain, spatially explicit, and relevantly scaled ecological data across multiple trophic levels important for maintaining ecosystem function and biodiversity (Pittman et al. 2011). Species distribution modelling (SDM) has been used as a tool to obtain this data and inform marine spatial planning across a large range of ecosystems and taxa (e.g., Gogina and Zettler 2010; Reiss et al. 2011; McGowan et al. 2013; Benoit-Bird et al. 2013; Bertram et al. 2017).

The upwelling current of the Northeast Pacific Ocean, the California Current Ecosystem (CCE) extends from British Columbia (Canada) southward to the Mexico-USA border. The CCE is highly productive and is an important area for American and Canadian commercial fisheries catch (e.g., Ware and Thomson 2005). Euphausiids constitute a key energy pathway from phytoplankton to higher trophic levels within the CCE due to their high lipid content and tendency to aggregate in swarms (Siegel 2000). Euphausia pacifica and Thysanoessa spinifera are the dominant species in the northern CCE, and together form a large part of the diet of commercial predator species such as rockfish (Sebastes

Received 24 December 2020. Accepted 28 May 2021.

R. Evans. Institute of Ocean Sciences, Fisheries and Oceans Canada, 9860 West Saanich Road, Sidney, BC V8L 5T5, Canada.

S. Gauthier. Institute of Ocean Sciences, Fisheries and Oceans Canada, 9860 West Saanich Road, Sidney, BC V8L 5T5, Canada; Department of Biology, University of Victoria, Victoria, BC V8P 5C2, Canada.

C.L.K. Robinson. Pacific Biological Station, Fisheries and Oceans Canada, 3190 Hammond Bay Road, Nanaimo, BC V9T 6N7, Canada.

Corresponding author: Rhian Evans (email: rhian.evans@utas.edu.au).

(c) 2021 The Crown. Permission for reuse (free in most cases) can be obtained from copyright.com. 
spp.; Chess et al. 1988), salmon (Salmonidae spp.; Beacham 1986), tuna (Thunnus spp.; Alverson 1963), Pacific hake (Merluccius productus; Mackas et al. 1997; Tanasichuk 1999), and walleye pollock (Gadus chalcogrammus; Buckley et al. 2016). Euphausiids feature heavily in the diet of other forage species such as Pacific herring (Clupea pallasii; Godefroid et al. 2019), and a variety of other commercially important pelagic fish species (Robinson 2000). Euphausiids have also been identified as an important prey resource for numerous seabirds (Abraham and Sydeman 2004; Hipfner 2009), and whale species (Croll et al. 2005; Nickels et al. 2019).

Euphausiids exhibit intense patchiness in their distribution, with clustering of high biomass in some areas, and little to no biomass in other areas. The environmental and physical processes that result in aggregations of very high biomass of euphausiids (or "hotspots") in certain areas is of interest, as these areas will likely be important foraging regions for marine predators (Allen et al. 2001; Santora et al. 2011b; Nickels et al. 2019), and should therefore be areas of consideration for marine spatial planning. In the Northeast Pacific Ocean, extensive research has been completed characterising the response of euphausiid species to their environment in the broader context of space and time, and the in situ local conditions that result in the development of hotspots of biomass (e.g., Santora et al. 2011b, 2018; Dorman et al. 2015; Cimino et al. 2020). These studies include local dynamic processes such as ocean currents and productivity (Swartzman et al. 2005; García-Reyes et al. 2014), bathymetrical features such as the shelf break and canyon systems (Manugian et al. 2015; Santora et al. 2018; Rockwood et al. 2020), as well as Pacific-wide climate processes such as El Niño and the Pacific Decadal Oscillation (Francis et al. 2012; Lindegren et al. 2018). These climate processes influence euphausiid biomass over seasonal, interannual and decadal timeframes.

In some regions of the Northeast Pacific Ocean climate cycles have become less predictable and in the case of El Niño events, more frequent, which has been attributed to anthropogenic climate change (Di Lorenzo and Mantua 2016; Liu et al. 2017). Under increasing environmental variability, it has become apparent that to successfully forecast future returns of commercial fish stocks such as Pacific salmon, or to manage marine predator populations such as whales and seabirds, an understanding of the spatial and temporal variability of lower-trophic-level prey, such as euphausiids, is required. Forage species are often not well represented in ecosystem models, despite their importance (Essington and Plagányi 2014). To include forage species such as euphausiids, some estimate of production or biomass is needed, and how this changes spatially or through time in response to environmental cues. Observational data are often spatially and temporally patchy, therefore species distribution models (SDMs) are often used to infer the biomass and distribution of species across larger areas for management purposes.

SDMs come with their own set of considerations and complications, such as data biases associated with sampling irregularities, spatial and temporal autocorrelation, missing data, and correlation among predictor variables. Many of these biases can now be accounted for through sophisticated modelling frameworks, for example, machine learning (Elith et al. 2008) or geostatistical techniques (Shelton et al. 2014; Thorson et al. 2015). There are many excellent reviews and discussions of SDMs in terms of statistical model structure, bias control, variance or error minimisation, evaluation, and model framework selection (e.g., Araújo and Guisan 2006; Elith and Leathwick 2009; Goethel et al. 2011; Dormann et al. 2013; Conn et al. 2015). Predictor variable selection with respect to the statistical limitations of the modelling framework being used, or statistical methods for covariate selection, have also been thoroughly reviewed in the literature (Austin and Smith 1990; Mac Nally 2000, 2002; Franklin 2010), and will not be further discussed here. However, outside of statistical bestpractice for distribution models, there are still many decisions made by the modeller that are crucial to the quality and precision of results and model predictions, but are highly subjective. What variables to include or what spatial scale to model at depends on the ecology and life history of the species being modelled, and the questions driving model development in the first place.

The main objective of this review was two-fold; to discuss and evaluate some of the more subjective choices made by ecologists employing euphausiid SDMs in the Northeast Pacific Ocean, and to synthesise results from environment-euphausiid SDMs for the two key species of euphausiids (E. pacifica and T. spinifera) in this region. The study area was defined as the coastal region of the California Current Ecosystem where euphausiids are numerically abundant. More specifically, we reviewed current published studies to answer the following questions: (1) How do the questions driving modelling affect the choices the modeller makes around model resolution? (2) What physical and habitat variables should be included in SDM modelling for E. pacifica and T. spinifera in this region, and are there differences between the two species? (3) Are the same variables important for modelling variability in the spatial structure (patchiness) of euphausiid biomass (i.e., hotspot development, intensity and persistence)? (4) Should temporal lags for predictor variables be included in SDMs, and which variables should be lagged? We aimed to discuss these questions, and where possible provide some recommendations, through a rigorous literature review. Although we have focused on the Northeast Pacific Ocean, insights provided by this synthesise can guide SDM efforts for euphausiids in coastal regions worldwide. This type of modelling is the first step towards forecasting changes in this underling prey field for ecosystem management under future climate change scenarios.

\section{Methods}

A literature search was conducted between October 2019 and November 2020 using SCOPUS, Web of Science and Google Scholar. Search terms and categories can be found in Table 1 . The search area was between California (the USA-Mexico border) and Canada (the Canadian-Alaska border) - see Fig. 1. Studies from the tropical Baja region at the southern end of the CCE, and studies from the more polar Alaskan coast were excluded due to differences in oceanography and euphausiid community species composition. Articles were excluded if the title and abstract were not related to environmental, physical or chemical oceanographic drivers of euphausiid distribution or biomass. Experimental laboratory studies were included if they pertained directly to the survival of E. pacifica or T. spinifera. Over 200 studies were included in the review.

For detailed analysis, euphausiid-environment studies were only included if they used quantitative analysis to link some aspect of the ecology of E. pacifica or T. spinifera with an environmental variable in the study region. Each article was reviewed and the following information extracted for entry into a database that can be viewed in the Supporting Information ${ }^{1}$ : citation and title of article; euphausiid species; area of study (including column for the latitude of the study region and a broad spatial region, see below); model spatial-temporal resolution; analytical approach (with the statistical modelling framework used recorded in a separate column); response averaging; environmental averaging; all lag phases tested for modelling (significant lag phase denoted by *); and, list of variables tested (significance denoted by ${ }^{*}$ and the direction indicated by,+- , or nonlinear). Specific sections of the CCE and British Columbia coast were separated into broad spatial regions (see Fig. 1). These sections were divided

${ }^{1}$ Supplementary data are available with the article at https://doi.org/10.1139/cjfas-2020-0481. 
Table 1. Search terms used in literature search.

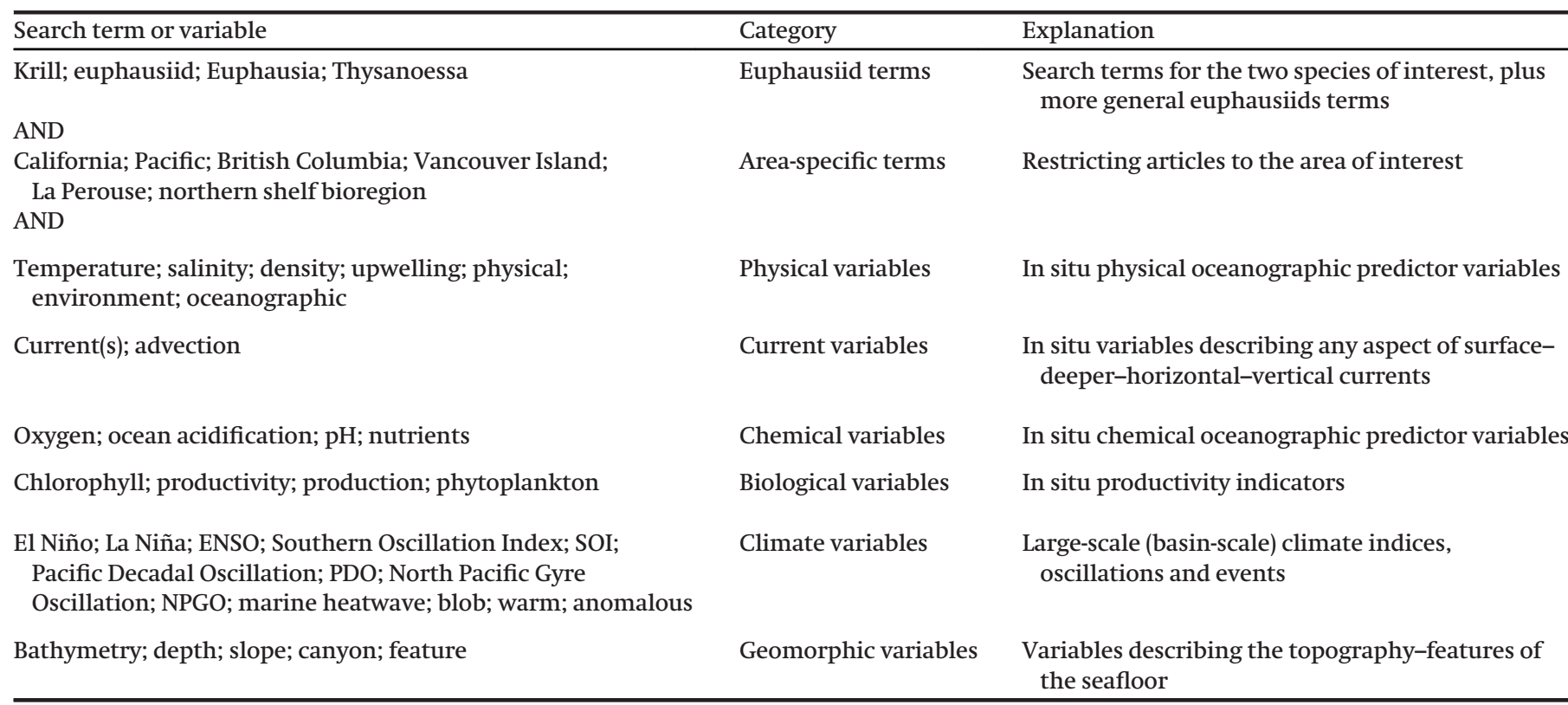

Note: The search terms were constructed using "Boolean" operators. Search words within cells of the first column were searched with "OR" between them; the

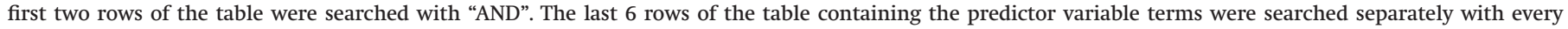
combination of euphausiids terms and area-specific terms.

based on latitude and represent different oceanographic regions within the CCE and British Columbia coast (see Fig. 1 and Table 2 for latitude groupings).

Predictor variables were separated into 27 variable categories (see Table 2 and Table 3 for groupings). Predictor variables were only recorded in the database if they were included in final models, and therefore were correlated with euphausiid information. For example, any predictor variable that was excluded prior to final modelling due to collinearity issues with another variable was not included in the database. Physical variables included temperature, salinity and a measure of water-column stratification (density, mixed-layer depth and stratification variables). These variables could be a mean across the water column, surface variables, or describe the environment at depth (see Table 3). Upwelling variables derived from Bakun's index or another kind of upwelling index were separated from wind and currents as an important feature of this ecosystem. Wind variables consisted of alongshore and cross-shore wind speed, and wind stress curl; current variables were north-south and east-west current speed, mostly at the surface, but with some models including a description of currents at depth, or vertical currents (see Table 3). In addition, eddy kinetic energy and sea-surface height were also included, as important descriptors of the physical environment. In situ chemical variables included ocean acidification, oxygen and nutrients. Biological variables included measures of chlorophyll and productivity (see Table 3). Climate variables were separated into their separate indices. Depth was separated from seafloor slope-rugosity as depth exhibits a known (and separate) relationship with the distribution of these two species of euphausiids, and these species also are known to exhibit relationships with changes in the aspect of the seafloor along the continental slope and canyon edges (here defined as slope-rugosity). A complete list of predictor variables used in models reviewed can be found in Table 3. The modelling approach was classified according to whether the statistical method used was univariate, bivariate (correlation analysis), multivariate, some form of regression, a simulation study or machine learning. More information on the method used to categorise difference aspects of studies into the database can be found in Table 2 .
To investigate the effects of environmental predictor variables on the species of interest (E. pacifica, T. spinifera), the results of models analysed were broken down into single relationships where possible. If multiple models were run in a single article, either with multiple species-groups of euphausiids or different groupings of environmental variable or different model types (e.g., regression and multivariate analysis such as PCA), they were treated as separate entries to the database and collated separately. Therefore, the number of articles does not equal the number of models reviewed (number of articles reviewed $=45$; number of models reviewed $=68$ ). For the rest of this manuscript, we talk about individual models, rather than individual articles (or studies). Temporal lags applied to specific predictor variables were also recorded in the database; we recorded which predictor variables were tested with a lag(s) applied, and whether it was significant or not.

We calculated summary statistics for the significance of variables based on the total number of models that tested each predictor variable, and then calculated the proportion of models that the predictor was significant. Therefore, each summary percentage is scaled by the number of models the variable was tested in, to make percentages comparable between variables. To analyse the proportion of models in which predictor variables with lags applied were significant, we calculated proportions based on a subset of the models that tested lags $(n=24)$, as all of the studies that included lags also tested the correlation of the variable with no lag applied.

\section{Results}

All articles analysed in this review can be viewed in the database provided with the Supplementary material ${ }^{1}(n=45)$. Studies analysed sampled the study area over a period of 67 years, between 1951 (Lilly and Ohman 2018) and 2018 (Cimino et al. 2020; Robertson and Bjorkstedt 2020).

\subsection{Distribution and resolution of modelling studies}

Central California was the most modelled region in studies analysed in this review $(n=22)$, followed by southern British 
Fig. 1. The spatial distribution of quantitative studies modelling links between the environment and E. pacifica and T. spinifera in the Northeast Pacific Ocean. Y axis of bar-plots represent the total count of studies reviewed in each region. Spatial regions are delineated by latitude (see Table 2 and Supplementary database ${ }^{1}$ ). Light grey dashed lines indicate the major currents in this region - the equatorwardflowing California Current and the poleward-flowing Alaska Current. Major Canadian-USA cities are labelled for anchoring purposes. Figure created in R version 4.0.4 through "PBSmapping" (Schute et al. 2021) package, which uses maps from the open source dataset GSHHG. [Colour online.]

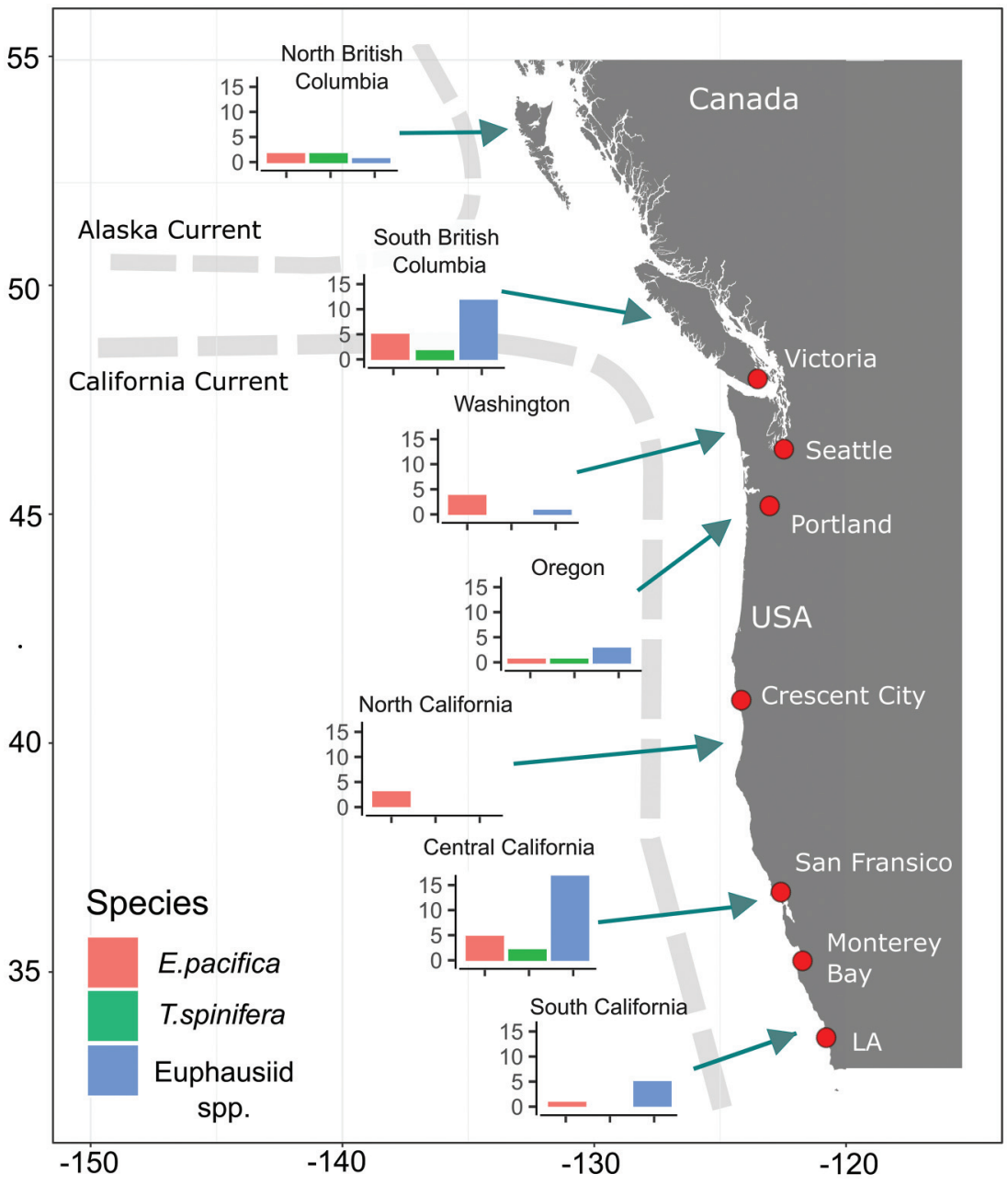

Columbia, where studies were mostly located off the southwest coast of Vancouver Island $(n=16$, see Fig. 1$)$. Northern California and Oregon were the least modelled regions considered in this review (both $n=4$ ). Two models analysed the whole of the California Current to $48^{\circ} \mathrm{N}$ (modelling the euphausiid community together), and are not displayed in Fig. 1. Eleven studies directly analysed the spatial structure of euphausiid biomass at the patch, aggregation or "hotspot" level. 63\% of models analysed were based on spring-summer euphausiid abundance-biomass, and monthly or seasonal averaging of environmental variables, with $27 \%$ of these also including a spatial modelling component via grid-based analysis or station-specific analysis. Other methods included seasonal means across all seasons, monthly means, bi-weekly means or station-by-station, and annual averaging across seasons. Spatial models utilised grid-based averaging across years at a resolution of between $1 \mathrm{~km}^{2}$ (Benoit-Bird et al. 2019) and $100 \mathrm{~km}^{2}$ (Santora et al. 2012b). Simulation studies analysed used simulated daily production as the response variable. The full list of response variables tested in articles reviewed can be found in Table 4 .

The choice of averaging both response and predictor variables across space or time was often associated with the scale of hypotheses and questions driving the modelling. For example, Benoit-Bird et al. (2019) were interested in quantifying the fine scale oscillations of periodic reversals of upwelling favourable winds and relaxation events through one upwelling season on the distribution of euphausiids off California, the effects of which had not been previously studied. Therefore, one season of data was adequate to address their aims; however, they required high resolution temporal and spatial sampling across this period. On the other hand, for several of the hotspot studies examining the spatial structure of the distribution of euphausiid biomass in relation to environmental variables, spatial averaging across years was appropriate to address questions regarding the mean distribution of areas of high biomass within an area that could then be linked with marine predator distribution (e.g., Santora et al. 2012a, 2014). 45\% of models analysed used some form of regression analysis to link the environment with euphausiids. Regression analyses included: step-wise, ordered logistic, linear and linear mixed models, generalised linear models (GLMs) and mixed-models (GLMMs), generalised additive models (GAMs) and GAMs with an autoregressive component. Out of these, GAMs were the most commonly used statistical analysis. 
Table 2. Column headings and explanation for categorisation of articles reviewed into the Supplementary database ${ }^{1}$.

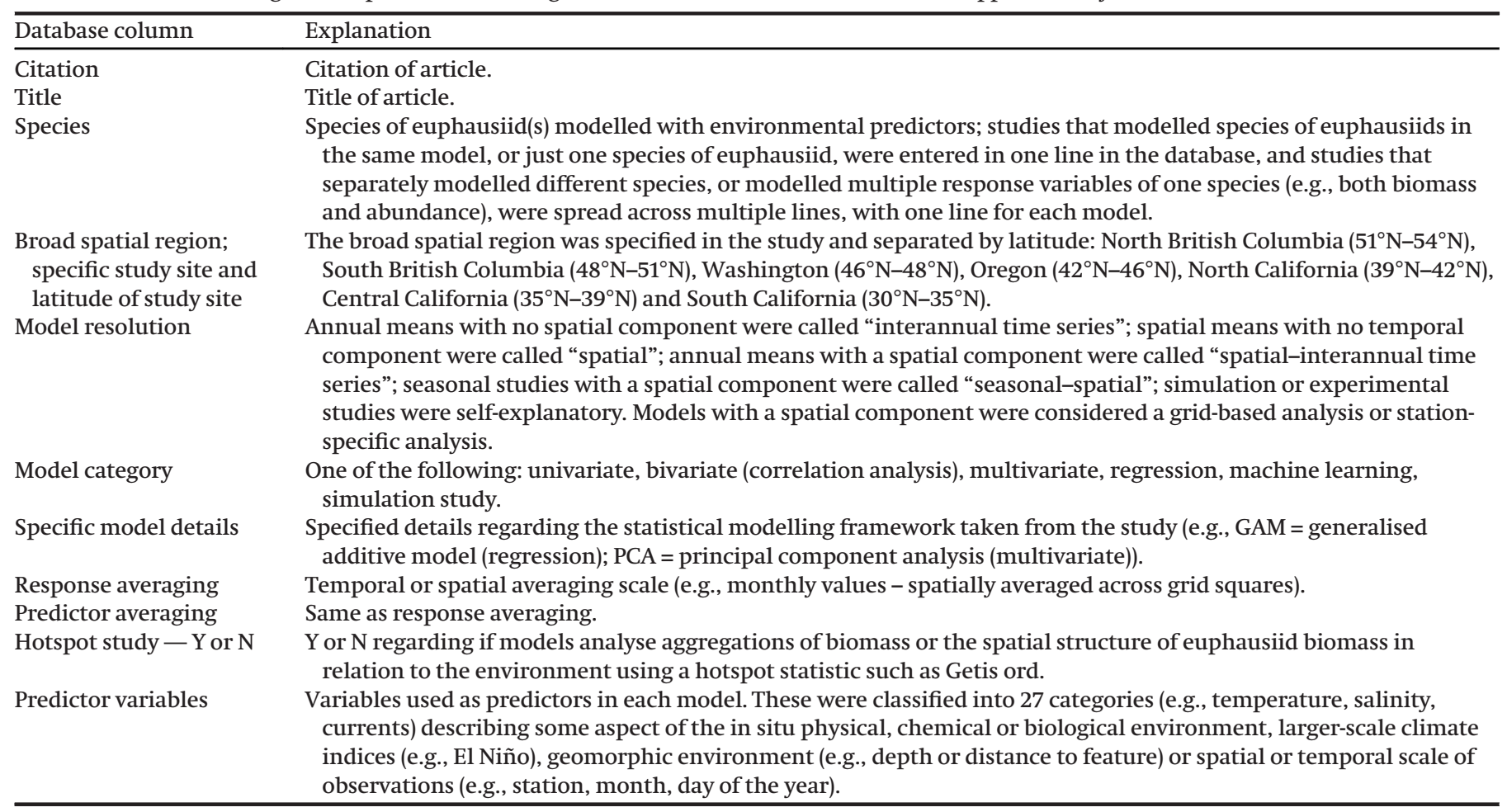

\subsection{Significant relationships between euphausiids and predictor variables}

Predictor variables were highly diverse and described some aspect of the in situ physical, chemical, biological, and bathymetrical environment, or basin-level annual or interannual patterns in climate oscillations. Water temperature was the most commonly modelled predictor $(n=57)$, closely followed by distance to features such as the coast or depth contours that relate to euphausiid ecology ( $n=43$; Fig. 2 ). Out of 413 correlations tested, 183 were found to be significant; 74 negative, 63 positive and 46 nonlinear responses. Latitude and longitude spatial attributes were most frequently significantly correlated with euphausiids. Next, ocean currents, the Southern Oscillation Index (SOI), ocean acidification (or $\mathrm{CO}_{2}-\mathrm{pH}$ ), chlorophyll, Pacific Decadal Oscillation (PDO), distance to feature, El Niño and depth, were all correlated significantly with euphausiids in $>50 \%$ of the models in which they were tested (Fig. 2). Water temperature was significantly correlated in $42 \%$ of models in which it was used as a predictor $(n=57)$, and was the variable most often included in modelling exercises. The highest proportion of correlations between water temperature and euphausiids were negative (Fig. 2); however, there were also many positive and nonlinear correlations found. Ocean acidification exhibited a significant negative correlation with euphausiids in $100 \%$ of models examined ( $n=5$; Fig. 2 ). Correlations between oxygen-hypoxia and euphausiids were only significant in $13 \%$ of the models they were tested in $(n=8)$, and were also always negative. Chlorophyll exhibited the highest proportion of positive correlations with euphausiids, closely followed by the North Pacific Gyre Oscillation (NPGO) (tested in $n=29$ and $n=10$ models, respectively; Fig. 2 ).

\subsection{Predictor variable choice}

There was large variety in the predictor variables chosen to describe the environment in models reviewed (see Table 2). For example, for the predictor variable "temperature", variables described the sea surface temperature (SST), the integrated (whole water column) temperature (e.g., mean 0-100 m temperature), subsurface temperature $(30-40 \mathrm{~m})$ and deep temperature $(>100 \mathrm{~m})$. This was true for all variables. Climate indices were excluded from this part of the analysis as they were often represented by a single universal index (apart from ENSO; see Table 3). For variables that could describe conditions at different vertical levels of the ocean such as temperature and salinity, surface variables more often exhibited a significant relationship with euphausiids than subsurface variables (Table 3; Fig. 3a). The largest range of variables were tested for stratification and currents $(n=$ 10 for both). Depth of the 26.0 isopycnal was the measurement of ocean stratification that most often exhibited a significant relationship with euphausiids in models it was tested in. Of the variables that described current patterns, surface east-west current speed (representing upwelling) was correlated significantly with euphausiids in the highest proportion of models in which it was tested.

Integrated variables, as a mean across the whole water column or sampling depth, exhibited the highest proportion of significant versus nonsignificant fits for both temperature and nutrients; however, the number of times integrated forms of these variables were included in models were much lower than for surface or subsurface variables (see Fig. 3a). Physical variables that described spatial differences in the marine environment were also included, for example coastal temperature from lighthouse stations around the coast, or offshore temperature from buoys. Anomalies from long time series were used to highlight temporal differences in physical variables; however, these anomalies were not often significant drivers of euphausiids in the models in which they were tested (see Table 3).

There was large variety in the variables used to describe geomorphic habitat features across models; many studies used a measure of the distance to specific local features such as islands to highlight differences in depth gradients, or to a specific depth feature such as the $200 \mathrm{~m}$ depth contour, which was often used to represent the continental shelf break (Fig. 3b). Distance to islands 
Table 3. All predictor variables tested in reviewed models, the number of times they were significant or not, along with the percentage of their ratio.

\begin{tabular}{|c|c|c|c|c|c|}
\hline Variable class & Variable form & $\begin{array}{l}\text { No. of } \\
\text { models sig. }\end{array}$ & $\begin{array}{l}\text { No. of models } \\
\text { not sig. }\end{array}$ & $\begin{array}{l}\text { Total no. } \\
\text { tested }\end{array}$ & $\%$ sig. \\
\hline \multirow{5}{*}{ Temperature } & SST (station) & 11 & 13 & 24 & 45.8 \\
\hline & SST standard deviation (for fronts) & 1 & 2 & 3 & 33.3 \\
\hline & Coastal SST & 1 & 4 & 5 & 20 \\
\hline & Anomaly & 1 & 4 & 5 & 20 \\
\hline & Deeper temp. (75-150) & 0 & 3 & 3 & 0 \\
\hline \multirow[t]{6}{*}{ Salinity } & SSS (station) & 5 & 10 & 15 & 33.3 \\
\hline & Bottom salinity & 0 & 2 & 2 & 0 \\
\hline & Midwater salinity (20-50 m) & 3 & 7 & 10 & 30 \\
\hline & Coastal salt & 1 & 2 & 3 & 33.3 \\
\hline & Anomaly & 0 & 3 & 3 & 0 \\
\hline & Deeper salinity (75-150) & 0 & 1 & 1 & 0 \\
\hline \multirow{9}{*}{ Density-stratification } & Brunt Väisälä frequency (integrated) & 0 & 3 & 3 & 0 \\
\hline & Depth of max. Brunt Väisälä frequency (BV) & 0 & 1 & 1 & 0 \\
\hline & Max. Brunt Väisälä frequency (BV) & 0 & 1 & 1 & 0 \\
\hline & Depth 26.0 isopycnal & 2 & 1 & 3 & 66.7 \\
\hline & Density difference between surface and 30-50 m & 0 & 2 & 2 & 0 \\
\hline & Density difference between surface and depth (200 m) & 0 & 2 & 2 & 0 \\
\hline & Density $\sigma \mathrm{T}$ & 0 & 5 & 5 & 0 \\
\hline & Mixed layer depth & 1 & 0 & 1 & 100 \\
\hline & Stratification strength integrated & 0 & 1 & 1 & 0 \\
\hline \multirow[t]{3}{*}{ Upwelling } & Bakun's Upwelling Index & 9 & 8 & 17 & 52.9 \\
\hline & Bakun's Upwelling Index — anomaly & 1 & 3 & 4 & 25 \\
\hline & Upwelling intensity & 1 & 1 & 2 & 50 \\
\hline \multirow{2}{*}{ Wind } & North-south wind speed & 0 & 2 & 2 & 0 \\
\hline & North-south wind speed anomaly & 0 & 2 & 2 & 0 \\
\hline \multirow[t]{9}{*}{ Currents } & Poleward transport centroid & 1 & 0 & 1 & 100 \\
\hline & Tidal and buoyancy currents & 1 & 0 & 1 & 100 \\
\hline & Ekman transport & 1 & 0 & 1 & 100 \\
\hline & Cross-shore tilt of isopycnals (from surface and depth currents) & 1 & 0 & 1 & 100 \\
\hline & Winter shear index & 0 & 1 & 1 & 0 \\
\hline & North-south transport & 1 & 1 & 2 & 50 \\
\hline & Surface north-south current $(V)$ & 3 & 3 & 6 & 50 \\
\hline & Surface east-west current $(U)$ & 4 & $\mathbf{1}$ & 5 & 80 \\
\hline & Vertical velocity at $40 \mathrm{~m}$ & 0 & 1 & 1 & 0 \\
\hline \multirow[t]{6}{*}{ Chlorophyll } & Satellite chlorophyll $a$ & 5 & 3 & 8 & 62.5 \\
\hline & Integrated (mean) fluorescence (70-100 m) & 3 & 4 & 7 & 42.9 \\
\hline & Surface fluorescence & 5 & 2 & 7 & 71.4 \\
\hline & Vertical profile of fluorescence & 0 & 2 & 2 & 0 \\
\hline & Mixed layer fluorescence & 1 & 1 & 2 & 50 \\
\hline & Midwater fluorescence (20-40 m) & 2 & 1 & 3 & 66.7 \\
\hline \multirow[t]{4}{*}{$p \mathrm{CO}_{2}-\mathrm{pH}$} & pH 7.69 & 1 & 0 & 1 & 100 \\
\hline & Elevated $\mathrm{CO}_{2}-1$ day & 0 & 1 & 1 & 0 \\
\hline & Elevated $\mathrm{CO}_{2}-21$ days & 1 & 0 & 1 & 100 \\
\hline & Elevated $p \mathrm{CO}_{2}$ & 1 & 0 & 1 & 100 \\
\hline
\end{tabular}


Table 3 (concluded).

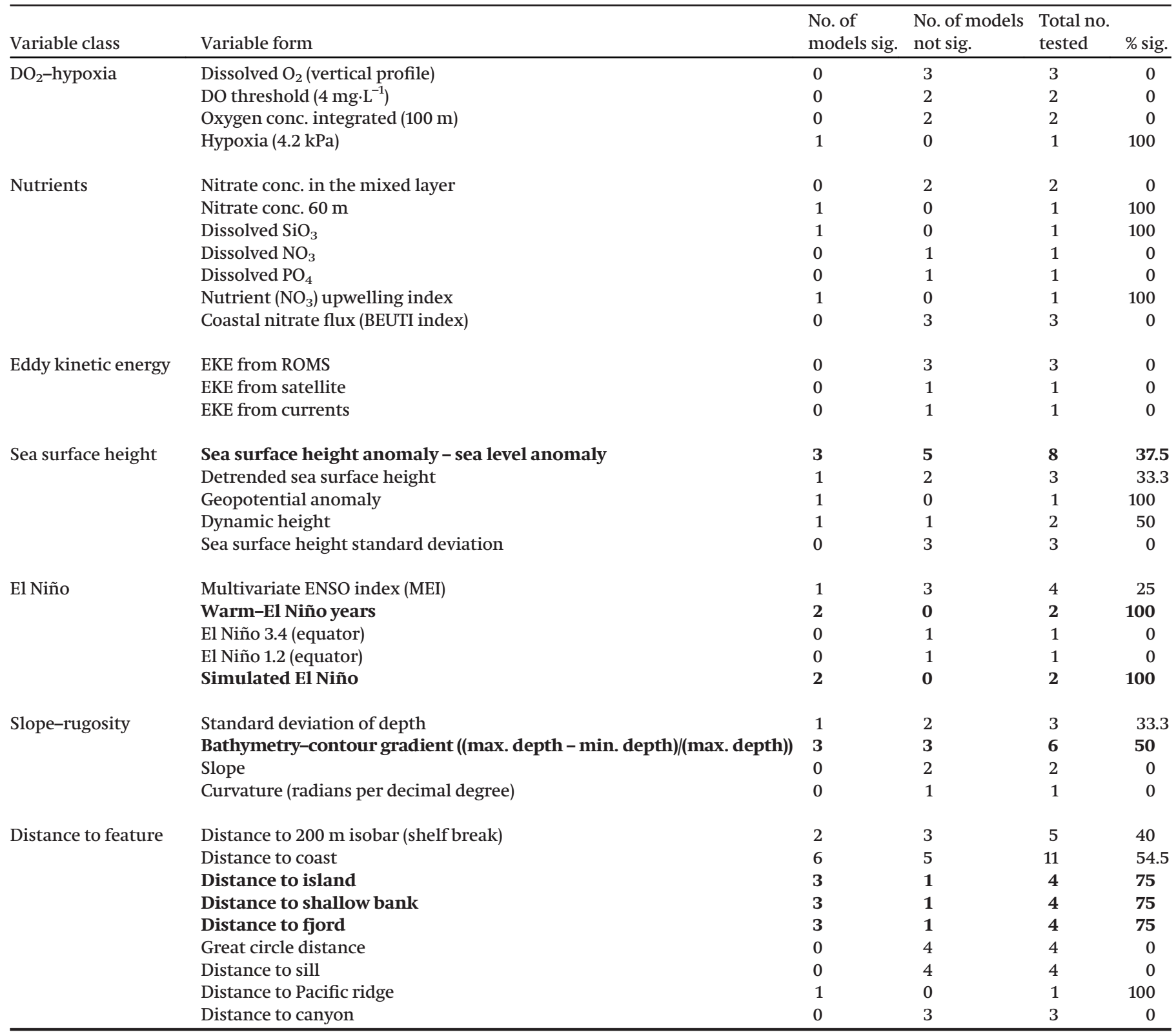

Note: Variables with the highest significance for each variable class are highlighted in bold (except where the variable was only tested once).

Table 4. Summary of response variables used to describe different aspects of euphausiid ecology in quantitative modelling in studies analysed.

\begin{tabular}{|c|c|}
\hline Response & $\begin{array}{l}\text { No. of } \\
\text { studies }\end{array}$ \\
\hline Abundance (integrated over whole water column or sampling depth; distribution) (number per $\mathrm{m}^{2}$ or per $\mathrm{m}^{3}$ ) & 16 \\
\hline Acoustic areal density NASC (Nautical Area Scattering Coefficient, units $\mathrm{m}^{2} \cdot \mathrm{n} \cdot \mathrm{mi}^{-2}$ ) (distribution; 1 nautical mile $=1.852 \mathrm{~km}$ ) & 12 \\
\hline Catch per unit effort (CPUE) (number·haul ${ }^{-1}$ ) & 8 \\
\hline Growth (length frequency, mm); survival (percent survival, \%); metabolism (respiration: oxygen consumption, $\mu \mathrm{mol} \mathrm{O}_{2} \cdot \mathrm{mg} \mathrm{dry} \mathrm{weight}^{-1} \cdot \mathrm{h}^{-1}$ ) & 7 \\
\hline Spatial patch structure-intensity (Z score from Getis ord, various hotspot statistics; see Supplementary material database ${ }^{1}$ ) & 4 \\
\hline Vertical presence or absence & 1 \\
\hline Vertical abundance (across depth layers, number per $\mathrm{m}^{2}$ or per $\mathrm{m}^{3}$ ) & 1 \\
\hline
\end{tabular}


Fig. 2. Percentage of models that found a significant relationship for each variable; colours indicate the type of relationship found (positive, negative and nonlinear). Numbers indicate the actual number of models tested for each variable. SOI - Southern Oscillation Index, PDO - Pacific Decadal Oscillation, NPGO - North Pacific Gyre Oscillation, EKE - eddy kinetic energy, NOI - Northern Oscillation Index, NPI - North Pacific Index. For variables with no bar, the number indicates how many models the variable was tested in but without any significant correlations. [Colour online.]

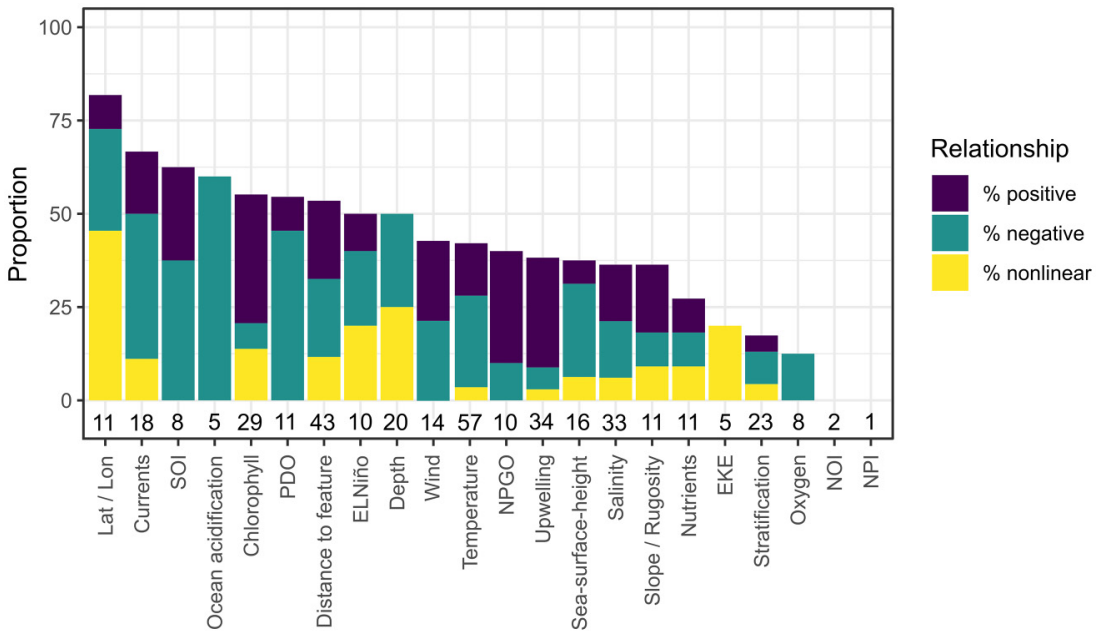

such as the Farallones Island; distance to seamounts such as the Cordell Bank area, and distance to fjord, were significant in the highest proportion of models that tested them (75\%; see Fig. $3 b)$.

\subsection{Species-specific differences in significant predictor variables}

Most models reviewed analysed total euphausiid abundance or biomass (60\%), therefore mostly representing E. pacifica and T. spinifera combined. These species are the dominant species in the study area, but total euphausiids also included occurrences of other euphausiids species such as T. inspinata or Nyctiphanes simplex. Species-specific models for E. pacifica and T. spinifera were few in comparison (40\%). Of those models that did separately analyse these species, $30 \%$ of models focused exclusively on E. pacifica, making this species comparatively more studied in quantitative modelling studies than T. spinifera ( $10 \%$ of model considered). Only a small number of studies $(n=5)$ ran separate models for E. pacifica and T. spinifera in the same article, and therefore used the same predictor variable selection process for both (Gomez-Gutierrez et al. 2005; Mackas et al. 2013; Sydeman et al. 2013; Qualls 2019; Cimino et al. 2020). This allowed comparisons of predictor variables exhibiting significant correlations with each species. Across the 5 studies, there were both similarities and differences in the predictors found to significantly correlate with each species. Qualls (2019) found similarities, with significant relationships between both species and temperature at $50 \mathrm{~m}$, sea surface salinity, mean chlorophyll $(0-70 \mathrm{~m})$, and distance to feature, common between the two species. Only two variables exhibited a significant relationship with just one species (E. pacifica): SST and depth. However, Cimino et al. (2020) did not find any commonality between the significant predictors for the two species and found more significant correlations with the predictors tested for $E$. pacifica $(n=6)$ than for T. spinifera $(n=4)$.

\subsection{Variables important for euphausiid hotspot development}

We reviewed 14 models that quantitatively linked environmental characteristics with the spatial structure, or patchiness, of euphausiid biomass. Only two of these models were species-specific; Dorman et al. (2015) modelled E. pacifica aggregations using an individual-based model, and Fiechter et al. (2020) used numerical models parameterised for E. pacifica. All other hotspot studies were based on euphausiid biomass as a whole, therefore there was no analysis of the spatial structure of solely T. spinifera biomass in relation to environmental drivers in the literature reviewed.

Significant relationships were found between euphausiid hotspots and environmental variables that promote high productivity, high survival, high recruitment and retention of euphausiids. There were some similarities in the predictor variables found to exhibit significant correlations with euphausiid hotspots across models, but there were some differences in the type of correlation found (Table 5). For example, seven of the studies analysed found increased upwelling, upwelling-favourable winds, and currents to exert a significant positive effect on the formation of euphausiid hotspots. However, four other studies found that advective currents such as Ekman's transport (commonly high during upwelling), negatively affected the development of euphausiid hotspots (see Table 5 for references). Also, both warmer and cooler temperatures were found to be positively correlated with euphausiid hotspots. These differences were not consistent across broad spatial regions but rather seemed to be reflective of very local oceanographic variability. Many of the variables found to be most significant for all other response variables described above (i.e., Fig. 2; latitude-longitude, currents, chlorophyll, climate indices, distance to features, depth) were also important in the development and persistence of euphausiid hotspots (Table 5).

\subsection{Temporal lag periods applied to predictor variables}

Out of the models considered in this synthesis, $38 \%$ included at least one temporal lag $(n=24)$. Lags ranged from 1 month to multiple years prior to euphausiid sampling. Not all predictor variables considered in reviewed models were tested with lags $(n=13$; Fig. 4). Out of the variables tested with a lag, temperature, salinity, stratification and currents were never significant with a temporal lag applied. Nutrients and chlorophyll were successfully modelled with lags in $n=1$ model each. Both of these variables were significant at a 1 month lag with euphausiid data (Fig. 4b). Lags applied to upwelling, wind, sea-surface height and largescale climate indices (El Niño, SOI, PDO, NPGO; Fig. 4a) were significant in a proportion of the models tested (14\%-38\%; Fig. $4 a)$. For the majority of these variables a 2-3 month lag period, or representing conditions from the previous winter, was the most successful (Fig. 4b). 
Fig. 3. Percentage of models that found a significant relationship for each variable tested in quantitative modelling studies analysed for (a) surface, subsurface and integrated forms of physical and biological water-column variables and (b) distance to different feature variables. Integrated variables are the mean from whole water column (surface to $\sim 75-100 \mathrm{~m}$ ). The number on each bar shows the number of models that tested each variable (i.e., the whole number each percent (\%) is scaled by); no bar indicates no significant relationships were found in the models run for that particular variable. [Colour online.]

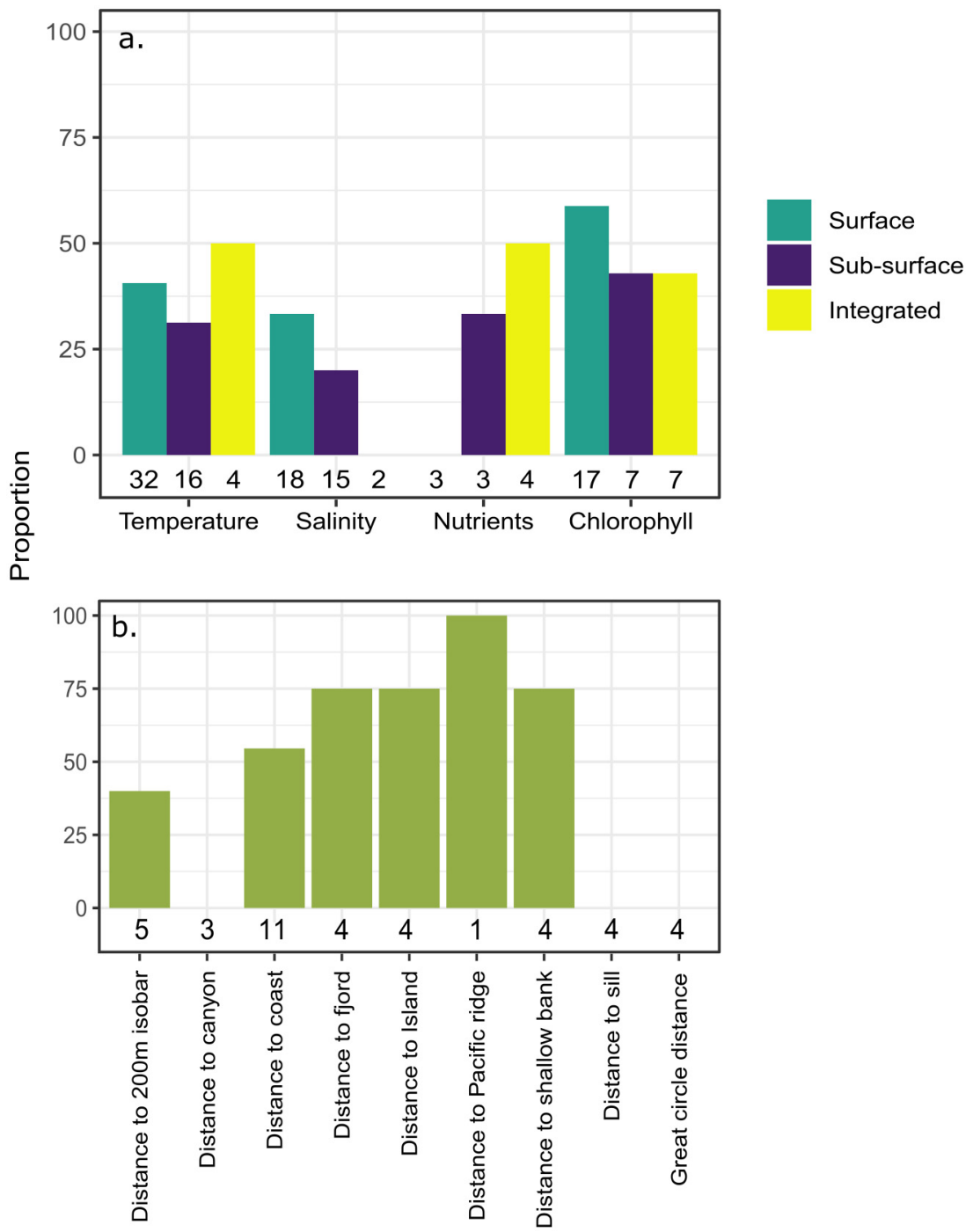

\section{Discussion}

For this review, we focussed on a small part of a much larger body of work to develop recommendations for ecologists developing statistical models to link euphausiids to their environment. The results of this review are reflective of the work that has been published on quantitative modelling of euphausiids in the Northeast Pacific Ocean, and are therefore inherently biased. For example, the results are skewed towards the region that has been most studied within this domain, which we have found to be the central Californian coast. This is important to keep in mind when interpreting the results, as the study area considered in this review exhibits high spatial variability in oceanographic and environmental characteristics, and these predictor variables can affect euphausiids in different ways depending on local climate and conditions (e.g., Peterson et al. 2006). In addition, a major aim of this synthesis was to provide some guidance on predictor variable selection for researchers modelling euphausiid biomass and distribution in this system. Therefore, to assess significance fairly, only predictor variables that were tested against each other in final models were included. Variables that were dropped at variable selection phases due to collinearity issues were not considered; this is another potential bias in our results.

\subsection{Predictor variable choice and selection}

In many ecosystems, predictor variable choice would be limited by the variables available. However, the CCE is a well-studied ecosystem, being regularly sampled as part of various long-term modelling studies such as GLOBEC and CALCOFI for over 50 years. This means there is a large array of possible predictor variables to choose from. Water temperature is often considered to be one of the most important physical variables shaping the biomass and distribution of marine species (e.g., Bosch et al. 2018). However, we found proportionally fewer significant correlations between E. pacifica and T. spinifera and temperature compared with some of the other variables tested in the modelling studies reviewed. In the models that did find a significant correlation with temperature, there was large variability in the response of euphausiids to changes in temperature, with only slightly more negative responses recorded than positive responses. In a system as large as the CCE, there is high variability in water temperatures 
Table 5. Variables with significant correlations with euphausiid hotspots.

\begin{tabular}{|c|c|}
\hline Marine environment variable & Reference(s) \\
\hline $\begin{array}{l}\text { Upwelling - proximity to upwelling centre - enhanced upwelling } \\
\text { favourable winds or currents }\end{array}$ & $\begin{array}{l}\text { Santora et al. 2011b, 2012a, 2014; Dorman et al. 2015; Benoit-Bird et al. 2019; } \\
\text { Fiechter et al. } 2020\end{array}$ \\
\hline Cool temperatures & Santora et al. 2014, 2018 \\
\hline Shallow pycnocline -26.0 isopycnal & Santora et al. 2012a; Fiechter et al. 2020 \\
\hline Enhanced nutrient concentrations & Fiechter et al. 2020 \\
\hline Chlorophyll $a$ concentration & Ressler et al. 2005; Santora et al. 2012a; Rockwood et al. 2020 \\
\hline $\begin{array}{l}\text { Retentive currents - reduced advective currents such as Ekman } \\
\text { transport }\end{array}$ & Santora et al. 2011b, 2012b; Rockwood et al. 2020; Swartzman et al. 2005 \\
\hline Moderate eddy kinetic energy & Santora et al. $2012 b$ \\
\hline Canyons & Santora et al. 2018 \\
\hline Negative phase of SOI, PDO; positive phase of NPGO & Rockwood et al. 2020 \\
\hline Latitude-longitude & Santora et al. 2011a, 2012b; Dorman et al. 2015 \\
\hline
\end{tabular}

between the more tropical southern CCE, and the more sub-Arctic northern coast of British Columbia. This makes temperature an important factor for species' survival, metabolism and growth (e.g., Li et al. 2019), but also the vertical and horizontal distribution of species with respect to the thermocline and species' thermal niche tolerances. Temperature can also be a proxy variable that describes changes in upwelling, and is therefore also reflective of productivity cycles and large-scale basin processes (Lluch-Cota et al. 2001). A large proportion of the studies considered correlated environmental variables with spring-summer biomass or abundance of euphausiids. Differences in temperature during this period reflect variability in the timing of the spring transition, with warmer years indicative of a later transition and cooler years indicative of an earlier transition. In models where multiple predictors were tested, variability associated with these processes was likely attributed to variables such as currents, wind, variables directly measuring upwelling (e.g., Kalyn 2014; Ralston et al. 2015), or to climate indies such as the PDO or El Niño, as SST is used to calculate these indices. All of these variables were proportionally more important than temperature for modelling euphausiids in this system.

Although we separated out predictor variable relationships with euphausiids to allow comparisons, within marine systems the effects of environmental variables and climate indices on biological communities are inter-linked, occur simultaneously, and are often describing different parts of the same dynamic process. In the CCE, changes in temperature and upwelling-favourable currents and winds are often localized signals of seasonal cycling. Multiple indices have been developed to link these annual changes with longer-term interannual or decadal oscillations; ENSO cycling, and a change in PDO and NPGO sign are tightly linked with in situ variability. For example, in the CCE, warm El Niño years, negative NPGO, and positive PDO phases are often associated with delayedonset and reduced intensity of springtime coastal upwelling (Yamada and Kosro 2010; Chenillat et al. 2012; Jacox et al. 2015). In addition, El Niño events are often associated with changes in the strength of coastal or upwelling currents (Hayward 1993; Chavez 1996), resulting in changes to species distributions (Brodeur 1986; Lavaniegos et al. 2002; Keister et al. 2005). Isopycnal tilt is a direct indication of the spring transition in the CCE (Lynn et al. 2003), and has also been used as a local indicator of El Niño (Lilly and Ohman 2018). This variable exerts a significant effect on euphausiid biomass and distribution (Santora et al. 2014; Fiechter et al. 2020).

Predictor variables that describe the subsurface ocean environment where euphausiids spend the majority of their life cycle during daylight hours, were significant in fewer models than surface variables. Euphausiids feed in surface waters at night on phytoplankton (Brinton 1967); surface conditions such as temperature and salinity may represent an indirect proxy for phytoplankton concentration, and may therefore have a more direct effect on euphausiid biomass and distribution. However, more numerous significant correlations with surface variables may simply be a factor of predictor variable availability, rather than ecology. Table 3 shows that for temperature and salinity, models that tested surface variables were more than double the number of integrated or subsurface variables. This demonstrates a common limitation of modelling exercises, and of this review, and reflects a bias in data availability, and perhaps researcher bias towards more readily available data sources. Due to satellite data, surface measurements of temperature and chlorophyll are now easily accessible for most areas.

\subsection{Choice of lag phase applied to predictor variables}

Difficulties in matching temporal and spatial scale between predictors and response variables mean many studies have failed to find quantifiable correlations. This difficulty extended to the addition of temporal lag phases applied to predictor variables where we would expect the response time of biological communities to lag environmental cues. We expected that these lagged variables might generate better correlations with euphausiids, as there are many instances in the literature of changes in euphausiid biomass and distribution lagging environmental perturbations. However, for the majority of variables tested this was not the case, and correlations with in situ physical conditions such as temperature and salinity were stronger than correlations with conditions in the water column that occurred previously.

Variables that did perform well with lag periods applied were tied to the date of the spring transition (e.g., upwelling, wind, and climate indices), with a lag of 2-3 months behind euphausiid sampling most often significant in modelling exercises (Robinson 1994; Ralston et al. 2015; Manugian et al. 2015; Rockwood et al. 2020). In the California Current, the transition from winter conditions to spring upwelling is known to happen quickly ( $\sim 1$ week; Strub et al. 1987); however, the specific date of this transition happens much earlier in the southern CCE than the northern CCE. For example, at $36^{\circ} \mathrm{N}$ off California, on average the spring transition happens around 30 January (Bograd et al. 2009), while along the British Columbia coast the transition is recorded to occur between April and May (Foreman et al. 2011). Three of the four studies mentioned above (Ralston et al. 2015; Manugian et al. 2015; Rockwood et al. 2020) were based off Central California, between $35^{\circ} \mathrm{N}$ and $39^{\circ} \mathrm{N}$, and sampling of euphausiid populations for these studies occurred in spring and summer (see Supplementary database ${ }^{1}$ ). Therefore, there is a lag of $\sim 3$ months between the spring transition and euphausiid sampling. Upwelling dynamics just prior to, or near the beginning of the spring transition, rather than at the 
Fig. 4. Variables tested with a lag phase as part of modelling in the literature reviewed. (a) Percentage of significant relationships for each variable that was tested with a lag applied, and percentage that were significant without a lag (even when a lag was also tested). (b) Length of lag phase tested; $Y$ axis is the number of models that tested each specific lag phase. Blue shows how many were significant and grey when a lag was tested but was not significant. SOI - Southern Oscillation Index, PDO — Pacific Decadal Oscillation, NPGO North Pacific Gyre Oscillation. [Colour online.]

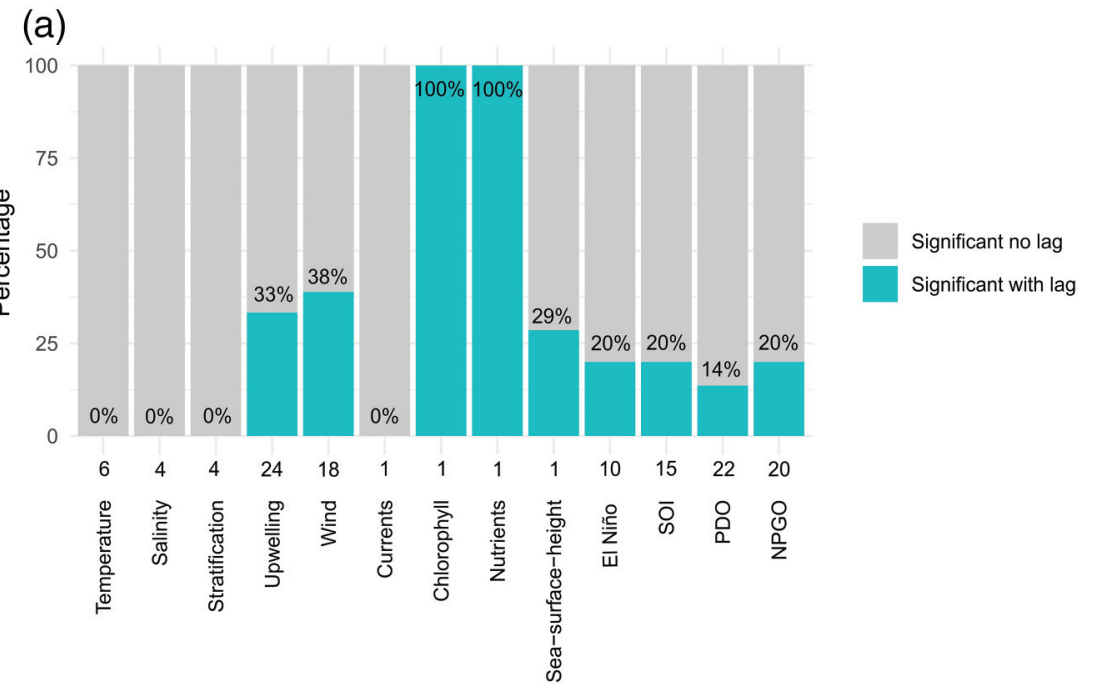

(b)
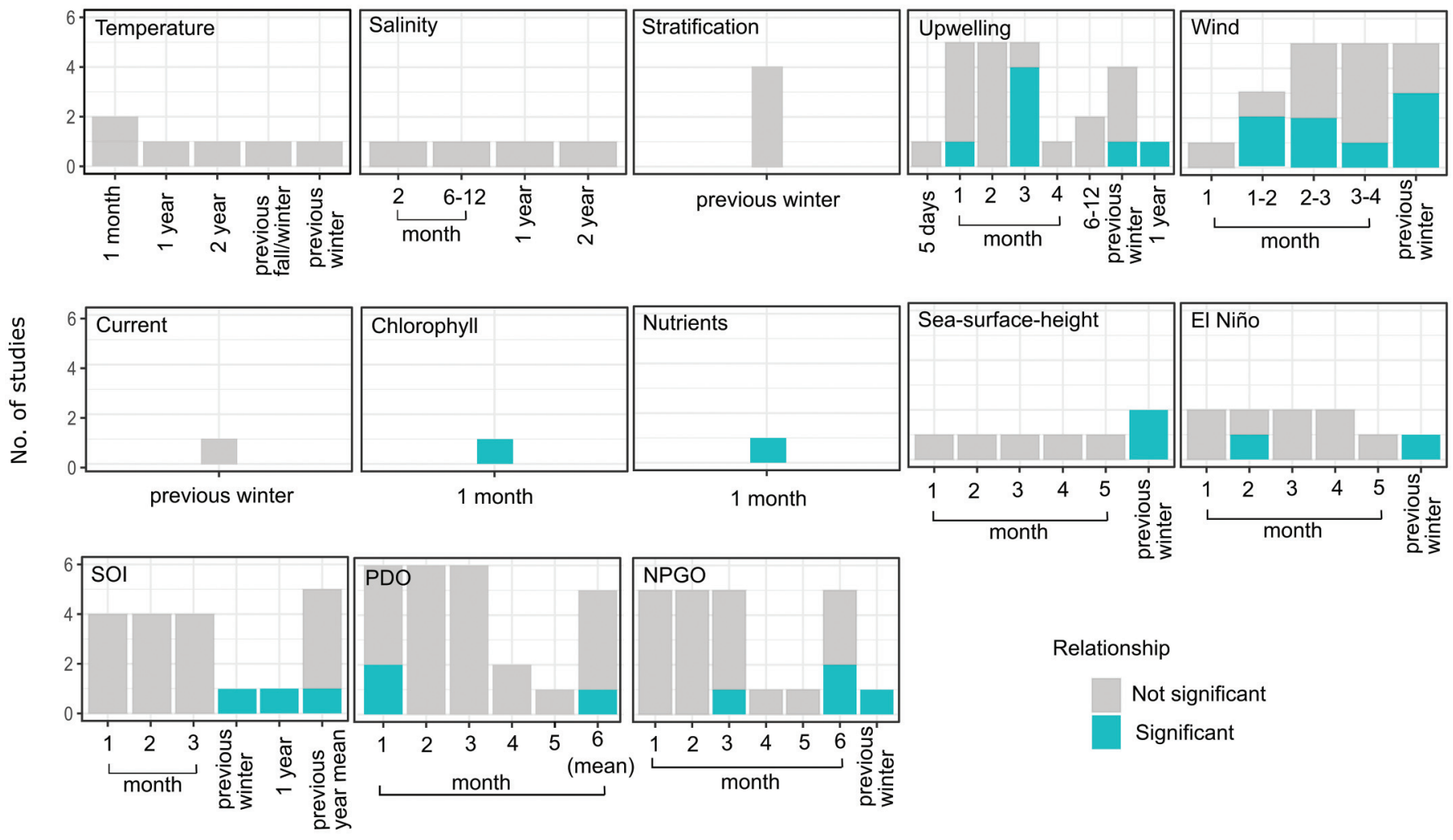

time of sampling, may therefore be more important for determining spring and summer euphausiid biomass and distribution in the CCE. This relationship has been found for other species within this ecosystem across trophic levels (e.g., for rockfish, salmon and seabirds), all of which feed on euphausiids (Logerwell et al. 2003; Black et al. 2010). There is evidence that winter wind conditions influences the timing and even the strength of the spring transition (Schroeder et al. 2013). Pulses of upwelling favourable winds just prior to the spring transition can provide a supply of nutrients to the upper water column that primes the system for high levels of primary production early in the upwelling season (Logerwell et al. 2003; Schroeder et al. 2009). Climate indices such as the NGPO and the PDO are reflective of these seasonal oceanographic cycles. Chenillat et al. (2012) demonstrate that the correlation between the NPGO index and upwelling favourable nearshore wind patterns is strongest during the wintertime off central California. 
Some studies have documented a lag in the response of biological community to climatic events. Lilly and Ohman (2018) implemented a 1-year lag when measuring the response of zooplankton biomass to an El Niño event due to reproduction. Following the 1997-1998 El Niño event, the macrozooplankton community off the west coast of Vancouver Island switched to a warm assemblage dominated by small copepods, and took months to return to a "boreal"-"sub-Arctic" assemblage (Mackas and Galbraith 2002). El Niño events are classified into Eastern Pacific (EP) and Central Pacific (CP) events, with differences in the evolution of these events in the equatorial pacific, physical expressions at mid- and high latitudes, and biological impacts (Ashok et al. 2007; Kao and Yu 2009). Fisher et al. (2015) found the response of copepods in the northern California Current to an EP event was rapid ( $\sim 2$ months), but responses to CP El Niño events were delayed ( 2-8 months). A contrasting view suggests that all El Niño events are some mixture of these two different types of forcing (Karnauskas 2013; Capotondi et al. 2015). Although many of the papers reviewed tested multiple temporal lag phases (Francis et al. 2012; Li et al. 2013; Sydeman et al. 2013; García-Reyes et al. 2014; Manugian et al. 2015; Cimino et al. 2020; Rockwood et al. 2020), a “one-size-fits-all” lag period applied to multiple El Niño events in a dataset may have little ecological relevance to the biological effects associated with multiple, very different, events across a time series.

\subsection{Spatial structure of euphausiid biomass and species- specific relationships between $E$. pacifica and T. spinifera and the marine environment}

The aggregating behaviour of euphausiids is arguably one of the main contributing factors to their role as a keystone species in the transfer of energy from primary production to higher trophic levels. The spatial structure of these aggregations dictates how biomass is distributed through an environment, and the degree of overlap between euphausiids and their predators in three dimensional space. Characterising the spatial structure of euphausiid aggregations in relation to their environment has been a focus of research over the last decade in the CCE (e.g., Ressler et al. 2005; Santora et al. 2011b, 2011a, 2018; Dorman et al. 2015; Benoit-Bird et al. 2019). The importance of edges along complex seafloor topography, such as shelf breaks and canyon edges, for the development of euphausiid aggregations is related to advective and retentive currents. Upwelling centres are areas of high advective processes, therefore, in the CCE, areas where high biomass of euphausiids develop are often situated south of upwelling centres, where the California Current (which flows equatorward) carries increased production from upwelling zones further south (Dorman et al. 2015). This pattern is most likely the reason that spatial attributes (latitude and longitude) were the variables most often found to exhibit a significant relationship with euphausiids in this region (e.g., Jahncke et al. 2008; Santora et al. 2011a, 2012b; Dorman et al. 2015). The spatial attributes in these models are therefore proxy variables describing conditions that are optimal for the development of high euphausiid biomass; distance from upwelling centres and southward flowing currents. Including a spatial component in these models accounts for multiple variables simultaneously, as well as accounting for some of the spatial dependence in the observed data and helping with spatial autocorrelation issues. Including spatial components in models however, is tied to the scale of the model, as the larger the scale of the study region, the more important the spatial component is likely to be compared to other predictor variables.

Santora et al. $(2011 b, 2012 b)$ found the aggregating behaviour of euphausiids to persist even at low overall biomass, therefore, overlap of euphausiid hotspot regions with areas of importance for marine predators is expected to be significant. Off the southwest British Columbia coast, the Juan de Fuca canyon system is a highly productive region for euphausiids, and has been identified as an important area for commercial fish such as Pacific hake and herring (Mackas et al.1997; Tanasichuk 2002; Godefroid et al. 2019), as well as critical habitat for recovering humpback (Megaptera novaeangliae) and killer whale (Orcinus orca) populations (Dalla Rosa et al. 2012; Ford et al. 2017). Many euphausiid predators display a species-specific preference for T. spinifera during at least part of the year. This is seen across diverse predator groups including Chinook salmon (Oncorhynchus tshawytscha), Cassin's auklet (Ptychoramphus aleuticus) and humpback whales (Abraham and Sydeman 2006; Wells et al. 2012; Nickels et al. 2018). Euphausia pacifica and T. spinifera are different sizes, have different nutritional values (Fisher et al. 2020), and reach peak biomass at different times during the spring and summer (Tanasichuk 1998a, 1998b; Feinberg and Peterson 2003; Feinberg et al. 2010). Therefore, mapping the persistence of speciesspecific hotspots with environmental variability will be an important consideration for conservation planning for euphausiid predators. However, particularly for T. spinifera, this currently represents a significant knowledge gap for this system.

The vast majority of studies analysed in this review modelled the total euphausiid community response to environmental or climate conditions. This is due, in part, to the development of sampling methods using acoustics to survey euphausiids. Acoustic methods exhibit some distinct advantages over net sampling for euphausiids; acoustic studies are now routinely carried out as part of commercial stock assessments. Therefore, there is often no additional cost for surveying euphausiids. Also, as this data are continuous, the spatial resolution is greatly increased. This allows analysis of the spatial structure of euphausiid aggregations at small spatial scales, which is not possible through net sampling. However, net-capture data allows species-specific analysis of euphausiid communities, which acoustic data does not.

Cimino et al. (2020) separately modelled the catch per unit effort of E. pacifica and T. spinifera off central California, and found that the two species significantly correlated with different environmental variables, at different temporal lags. As a comparison, they also modelled total euphausiid biomass, and found that the results of this model closely reflected the results of the E. pacifica model, but performed more poorly. Therefore, particularly in region like the CCE where there is a numerically dominant species, total euphausiid model results are likely to reflect the environmental preferences of that particular species, rather than a collective-community response. The poorer fit of the total euphausiid model compared with the two species models suggests it is important to separate euphausiid species prior to modelling. Studies analysed by this review that modelled the biomass and distribution of both E. pacifica and T. spinifera (separately) were few $(n=5)$. Results of the other studies analysed mirrored the results of Cimino et al. (2020), with significant differences in environment and habitat associations between the two species (Gomez-Gutierrez et al. 2005; Sydeman et al. 2013; Qualls 2019). Other studies considered the two species separately; however, those studies used multivariate statistics such as principal component analysis to reduce the dimensionality of results, which meant it was difficult to tease apart significant correlations with environmental predictors for each species (Mackas et al. 2001). Differences in the response of euphausiid species to environment and habitat variables suggests differences in distribution patterns are likely, and E. pacifica and T. spinifera often exhibit spatial partitioning (Mackas et al. 2001; Brinton and Townsend 2003). Due to differences in environmental correlations and distributions, our results indicate that species-specific hotspots are likely to occur throughout this region.

\subsection{Other challenges of euphausiid-environment modelling}

Quantitative inclusion of events such as the 2014-2016 marine heatwave into distribution models is challenging, and so far has been attempted by few studies (Lavaniegos et al. 2019; Cimino et al. 2020). However, results indicate that the response of euphausiids 
to these events are complicated and species-specific. Cimino et al. (2020) found that in general, E. pacifica and T. spinifera CPUE was lower than average during warm years off the central CCE, with the magnitude of anomalies greatest in 2015. However, while this was found on average over the whole system, more localized regional differences were found. Off northern California and southern Oregon, the predicted CPUE anomaly was positive for T. spinifera in 2015 during the marine heatwave, while in general E. pacifica CPUE in this area was negative (Cimino et al. 2020). This is surprising given that regional declines in T. spinifera have been recorded in multiple other studies following increases in surface temperatures associated with El Niño events (Brinton 1981; Tanasichuk 1998b; Marinovic et al. 2002). Positive anomalies of euphausiids during the 2014-2016 marine heatwave event were also observed along the west coast of Vancouver Island (southern British Columbia; Boldt et al. 2020). However, these results have not yet been quantitatively linked to changes in climate associated with the event on the British Columbia coast.

It is clear the response of euphausiids to these anomalous events is likely to be complex, and more work will need to be done characterising species' responses, particularly given the predicted increases in frequency forecasted for these events (Oliver et al. 2018). This review also highlights gaps in northern and temperate regions of the CCE regarding the inclusion of oxygen and increasing ocean acidification as predictor variables in species distribution modelling for euphausiids. Furthermore, climate indices such as the PDO and NGPO have not been analysed for their effects on euphausiid hotspot formation.

\section{Conclusions}

In summary, we have found that across the CCE and northern British Columbia, predictor variables that describe the spatial and geomorphic environment, and interannual variability in the timing of the spring transition and upwelling, are the best variables to include in environmental modelling of E. pacifica and T. spinifera. Temperature in this area is intrinsically linked with variability in upwelling, and may be a variable that, after initial exploratory analysis - variable selection, is discarded in favour of more direct measurements of wind and currents. Climate indices were also strong predictors of euphausiid biomass and distribution in this system. For these particular variables, lag periods should be tested as part of model development, and the specific lag that produces the best model fit will likely depend on the latitude of the study region. Finally, we advise more species-specific modelling exercises are needed, particularly describing the effect of environmental variability on the patchiness and persistence of T. spinifera biomass. Mapping hotspot regions of important lowertrophic-level groups such as euphausiids, ideally down to species differences, should be an important component of ecosystembased fisheries management (e.g., Kaplan et al. 2013; Fu et al. 2017). Determining if these regions are persistent or likely to fluctuate in response to ocean warming will greatly improve our forecasting ability for commercially important fish species, as well as other important predators including seabirds and marine mammal species. Ultimately, information on spatial and temporal variability in euphausiid production and aggregation will be crucial in developing effective, regionally specific models for marine-spatial planning, marine species at risk recovery, and fisheries forecasting.

\section{Acknowledgements}

This work was funded and supported by Fisheries and Oceans Canada as part of the Aquatic Climate Change Adaption Services Program.

\section{References}

Abraham, C.L., and Sydeman, W.J. 2004. Ocean climate, euphausiids and auklet nesting: inter-annual trends and variation in phenology, diet and growth of a planktivorous seabird, Ptychoramphus aleuticus. Mar. Ecol. Prog. Ser. 274: 235-250. doi:10.3354/meps274235.

Abraham, C.L., and Sydeman, W.J. 2006. Prey-switching by Cassin's auklet Ptychoramphus aleuticus reveals seasonal climate-related cycles of Euphausia pacifica and Thysanoessa spinifera. Mar. Ecol. Prog. Ser. 313: 271-283. doi:10.3354/ meps313271.

Allen, S.E., Vindeirinho, C., Thomson, R.E., Foreman, M.G., and Mackas, D.L. 2001. Physical and biological processes over a submarine canyon during an upwelling event. Can. J. Fish. Aquat. Sci. 58(4): 671-684. doi:10.1139/f01008

Alverson, F.G. 1963. The food of yellowfin and skipjack tunas in the eastern tropical Pacific Ocean. Inter Am. Trop. Tuna Comm. Bull. 7(5): 293-396.

Araújo, M.B., and Guisan, A. 2006. Five (or so) challenges for species distribution modelling. J. Biogeogr. 33(10): 1677-1688. doi:10.1111/j.1365-2699.2006.01584.x.

Ashok, K., Behera, S.K., Rao, S.A., Weng, H., and Yamagata, T. 2007. El Niño Modoki and its possible teleconnection. J. Geophys. Res. 112(C11). doi:10.1029/ 2006JC003798.

Austin, M., and Smith, T. 1990. A new model for the continuum concept. In Progress in theoretical vegetation science. Springer. pp. 35-47.

Beacham, T.D. 1986. Type, quantity, and size of food of Pacific salmon (Oncorhynchus) in the Strait of Juan de Fuca, British Columbia. Fish. Bull. 84(1): 77-90.

Benoit-Bird, K.J., Battaile, B.C., Heppell, S.A., Hoover, B., Irons, D., Jones, N., et al. 2013. Prey patch patterns predict habitat use by top marine predators with diverse foraging strategies. PLoS ONE, 8(1): e53348. doi:10.1371/journal. pone.0053348. PMID:23301063.

Benoit-Bird, K.J., Waluk, C.M., and Ryan, J.P. 2019. Forage species swarm in response to coastal upwelling. Geophys. Res. Lett. 46(3): 1537-1546. doi:10.1029/ 2018GL081603.

Bertram, D.F., Mackas, D.L., Welch, D.W., Boyd, W.S., Ryder, J.L., Galbraith, M., et al. 2017. Variation in zooplankton prey distribution determines marine foraging distributions of breeding Cassin's Auklet. Deep Sea Res. Part I Oceanogr. Res. Pap. 129: 32-40. doi:10.1016/j.dsr.2017.09.004

Black, B.A., Schroeder, I.D., Sydeman, W.J., Bograd, S.J., and Lawson, P.W. 2010. Wintertime ocean conditions synchronize rockfish growth and seabird reproduction in the central California Current ecosystem. Can. J. Fish. Aquat. Sci. 67(7): 1149-1158. doi:10.1139/F10-055.

Bograd, S.J., Schroeder, I., Sarkar, N., Qiu, X., Sydeman, W.J., and Schwing, F.B. 2009. Phenology of coastal upwelling in the California Current. Geophys. Res. Lett. 36(1). doi:10.1029/2008GL035933.

Boldt, J.L., Javorski, A., and Chandler, P.C. 2020. State of the physical, biological and selected fishery resources of Pacific Canadian Marine Ecosystems in 2019. Can. Tech. Rep. Fish. Aquat. Sci. 3377.

Bosch, S., Tyberghein, L., Deneudt, K., Hernandez, F., and Clerck, O.D. 2018. In search of relevant predictors for marine species distribution modelling using the MarineSPEED benchmark dataset. Divers. Distrib. 24(2): 144-157. doi:10.1111/ddi.12668.

Brinton, E. 1967. Vertical migration and avoidance capability of euphausiids in the California Current. Limnol. Oceanogr. 12(3): 451-483. doi:10.4319/ lo.1967.12.3.0451. PMID:32336785.

Brinton, E. 1981. Euphausiid distributions in the California Current during the warm winter-spring of 1977-78, in the context of a 1949-1966 time series. Calif. Coop. Oceanic Fish. Invest. Rep. 22: 135-154.

Brinton, E., and Townsend, A. 2003. Decadal variability in abundances of the dominant euphausiid species in southern sectors of the California Current. Deep Sea Res. Part II Top. Stud. Oceanogr. 50(14-16): 2449-2472. doi:10.1016/S0967-0645(03)00126-7.

Brodeur, R.D. 1986. Northward Displacement of the Euphausiid Nyctiphanes Simplex Hansen to Oregon and Washington Waters following the El Niño Event of 1982-83. J. Crustac. Biol. 6(4): 686-692. doi:10.2307/1548382.

Buckley, T.W., Ortiz, I., Kotwicki, S., and Aydin, K. 2016. Summer diet composition of walleye pollock and predator-prey relationships with copepods and euphausiids in the eastern Bering Sea, 1987-2011. Deep Sea Res. Part II Top. Stud. Oceanogr. 134: 302-311. doi:10.1016/j.dsr2.2015.10.009.

Capotondi, A., Wittenberg, A.T., Newman, M., Di Lorenzo, E., Yu, J.Y., Braconnot, P., et al. 2015. Understanding ENSO diversity. Bull. Am. Meteorol. Soc. 96(6): 921-938. doi:10.1175/BAMS-D-13-00117.1.

Chavez, F.P. 1996. Forcing and biological impact of onset of the 1992 El Niño in central California. Geophys. Res. Lett. 23(3): 265-268. doi:10.1029/ 96GL00017.

Chenillat, F., Rivière, P., Capet, X., Di Lorenzo, E., and Blanke, B. 2012. North Pacific Gyre Oscillation modulates seasonal timing and ecosystem functioning in the California Current upwelling system. Geophys. Res. Lett. 39(1). doi:10.1029/2011GL049966.

Chess, J.R., Smith, S.E., and Fischer, P.C. 1988. Trophic relationships of the shortbelly rockfish, Sebastes jordani, off central California. CalCOFI Rep. 29: 129-136.

Cimino, M.A., Santora, J.A., Schroeder, I., Sydeman, W., Jacox, M.G., Hazen, E.L., and Bograd, S.J. 2020. Essential krill species habitat resolved by seasonal upwelling and ocean circulation models within the large marine ecosystem of the California Current System. Ecography, 43: 15361549. doi:10.1111/ecog.05204. 
Conn, P.B., Johnson, D.S., Hoef, J.M.V., Hooten, M.B., London, J.M., and Boveng, P.L. 2015. Using spatiotemporal statistical models to estimate animal abundance and infer ecological dynamics from survey counts. Ecol. Monogr. 85(2): 235-252. doi:10.1890/14-0959.1

Croll, D., Marinovic, B., Benson, S., Chavez, F., Black, N., Ternullo, R., and Tershy, B. 2005. From wind to whales: trophic links in a coastal upwelling system. Mar. Ecol. Prog. Ser. 289: 117-130. doi:10.3354/meps289117.

Crowder, L., and Norse, E. 2008. Essential ecological insights for marine ecosystem-based management and marine spatial planning. Mar. Pol. 32(5): 772-778. doi:10.1016/j.marpol.2008.03.012.

Dalla Rosa, L., Ford, J.K., and Trites, A.W. 2012. Distribution and relative abundance of humpback whales in relation to environmental variables in coastal British Columbia and adjacent waters. Cont. Shelf Res. 36: 89104. doi:10.1016/j.csr.2012.01.017.

Di Lorenzo, E., and Mantua, N. 2016. Multi-year persistence of the 2014/15 North Pacific marine heatwave. Nat. Clim. Change, 6(11): 1042-1047. doi:10.1038/ nclimate3082.

Dorman, J.G., Sydeman, W.J., García-Reyes, M., Zeno, R.A., and Santora, J.A. 2015. Modeling krill aggregations in the central-northern California Current. Mar. Ecol. Prog. Ser. 528: 87-99. doi:10.3354/meps11253.

Dormann, C.F., Elith, J., Bacher, S., Buchmann, C., Carl, G., Carré, G., et al. 2013. Collinearity: a review of methods to deal with it and a simulation study evaluating their performance. Ecography, 36(1): 27-46. doi:10.1111/ j.1600-0587.2012.07348.x.

Douvere, F. 2008. The importance of marine spatial planning in advancing ecosystem-based sea use management. Mar. Pol. 32(5): 762-771. doi:10.1016/j. marpol.2008.03.021.

Douvere, F., and Ehler, C. 2009. Ecosystem-based marine spatial management: An evolving paradigm for the management of coastal and marine places. Ocean Yearbook Online, 23(1): 1-26. doi:10.1163/22116001-90000188.

Elith, J., and Leathwick, J.R. 2009. Species distribution models: ecological explanation and prediction across space and time. Annu. Rev. Ecol. Evol. Syst. 40: 677-697. doi:10.1146/annurev.ecolsys.110308.120159.

Elith, J., Leathwick, J.R., and Hastie, T. 2008. A working guide to boosted regression trees. J. Anim. Ecol. 77(4): 802-813. doi:10.1111/j.1365-2656.2008.01390.x.

Essington, T.E., and Plagányi, E.E. 2014. Pitfalls and guidelines for "recycling" models for ecosystem-based fisheries management: evaluating model suitability for forage fish fisheries. ICES J. Mar. Sci. 71(1): 118-127. doi:10.1093/icesjms/fst047.

Feinberg, L.R., and Peterson, W.T. 2003. Variability in duration and intensity of euphausiid spawning off central Oregon, 1996-2001. Prog. Oceanogr. 57(3-4): 363-379. doi:10.1016/S0079-6611(03)00106-X.

Feinberg, L.R., Peterson, W.T., and Shaw, C.T. 2010. The timing and location of spawning for the Euphausiid Thysanoessa spinifera off the Oregon coast, USA. Deep Sea Res. Part II Top. Stud. Oceanogr. 57(7-8): 572-583. doi:10.1016/j. dsr2.2009.10.007.

Fiechter, J., Santora, J.A., Chavez, F., Northcott, D., and Messié, M. 2020. Krill hotspot formation and phenology in the California Current Ecosystem. Geophys. Res. Lett. 47(13). e2020GL088039. doi:10.1029/2020GL088039.

Fisher, J.L., Menkel, J., Copeman, L., Shaw, C.T., Feinberg, L.R., and Peterson, W.T 2020. Comparison of condition metrics and lipid content between Euphausia pacifica and Thysanoessa spinifera in the northern California Current, USA. Prog. Oceanogr. 188: 102417. doi:10.1016/j.pocean.2020.102417.

Fisher, J.L., Peterson, W.T., and Rykaczewski, R.R. 2015. The impact of El Niño events on the pelagic food chain in the northern California Current. Global Change Biol. 21(12): 4401-4414. doi:10.1111/gcb.13054.

Ford, J.K., Pilkington, J.F., Otsuki, M., Gisborne, B., Abernethy, R.M., Stredulinsky, E.H., et al. 2017. Habitats of special importance to resident killer whales (Orcinus orca) off the west coast of Canada. Fisheries and Oceans Canada, Ecosystems and Oceans Science.

Foreman, M.G.G., Pal, B., and Merryfield, W.J. 2011. Trends in upwelling and downwelling winds along the British Columbia shelf. J. Geophys. Res. 116(C10). doi:10.1029/2011JC006995.

Francis, T.B., Scheuerell, M.D., Brodeur, R.D., Levin, P.S., Ruzicka, J.J., Tolimieri, N., and Peterson, W.T. 2012. Climate shifts the interaction web of a marine plankton community. Global Change Biol. 18(8): 2498-2508. doi:10.1111/j.1365-2486.2012.02702.x.

Franklin, J. 2010. Mapping species distributions: spatial inference and prediction. Cambridge University Press

Fu, C., Olsen, N., Taylor, N., Grüss, A., Batten, S., Liu, H., et al. 2017. Spatial and temporal dynamics of predator-prey species interactions off western Canada. ICES J. Mar. Sci. 74(8): 2107-2119. doi:10.1093/icesjms/fsx056.

García-Reyes, M., Largier, J.L., and Sydeman, W.J. 2014. Synoptic-scale upwelling indices and predictions of phyto- and zooplankton populations. Prog. Oceanogr. 120: 177-188. doi:10.1016/j.pocean.2013.08.004

Godefroid, M., Boldt, J.L., Thorson, J.T., Forrest, R., Gauthier, S., Flostrand, L., et al. 2019. Spatio-temporal models provide new insights on the biotic and abiotic drivers shaping Pacific Herring (Clupea pallasi) distribution. Prog. Oceanogr. 178: 102198. doi:10.1016/j.pocean.2019.102198.

Goethel, D.R., Quinn, T.J., II., and Cadrin, S.X. 2011. Incorporating spatial structure in stock assessment: movement modeling in marine fish population dynamics. Rev. Fish. Sci. 19(2): 119-136. doi:10.1080/10641262.2011.557451.

Gogina, M., and Zettler, M.L. 2010. Diversity and distribution of benthic macrofauna in the Baltic Sea: Data inventory and its use for species distribution modelling and prediction. J. Sea Res. 64(3): 313-321. doi:10.1016/j.seares.2010.04.005.

Gomez-Gutierrez, J., Peterson, W.T., and Miller, C.B. 2005. Cross-shelf life-stage segregation and community structure of the euphausiids off central Oregon (1970-1972). Deep Sea Res. Part II Top. Stud. Oceanogr. 52(1-2): 289-315. doi:10.1016/j.dsr2.2004.09.023.

Hayward, T.L. 1993. Preliminary observations of the 1991-1992 El Niño in the California Current. Calif. Coop. Oceanic Fish. Invest. Rep. 34: 21-29. doi:10.1029/96JC03050.

Hipfner, J. 2009. Euphausiids in the diet of a North Pacific seabird: annual and seasonal variation and the role of ocean climate. Mar. Ecol. Prog. Ser. 390: 277-289. doi:10.3354/meps08209.

Jacox, M.G., Fiechter, J., Moore, A.M., and Edwards, C.A. 2015. ENSO and the California Current coastal upwelling response. J. Geophys. Res. Oceans, 120: 1691-1702. doi:10.1002/2014JC010650.

Jahncke, J., Saenz, B.L., Abraham, C.L., Rintoul, C., Bradley, R.W., and Sydeman, W.J. 2008. Ecosystem responses to short-term climate variability in the Gulf of the Farallones, California. Prog. Oceanogr. 77(2-3): 182-193. doi:10.1016/j.pocean.2008.03.010.

Kalyn, S.L. 2014. The impact of ocean climate variability on prey availability and the reproductive performance of a planktivorous seabird, ancient murrelet (Synthliboramphus antiquus). Royal Roads University (Canada).

Kao, H.-Y., and Yu, J.-Y. 2009. Contrasting eastern-Pacific and central-Pacific types of ENSO. J. Clim. 22(3): 615-632. doi:10.1175/2008JCLI2309.1.

Kaplan, I.C., Brown, C.J., Fulton, E.A., Gray, I.A., Field, J.C., and Smith, A.D.M. 2013. Impacts of depleting forage species in the California Current. Environ. Conserv. 40(4): 380-393. doi:10.1017/S0376892913000052.

Karnauskas, K.B. 2013. Can we distinguish canonical El Niño from Modoki? Geophys. Res. Lett. 40(19): 5246-5251. doi:10.1002/grl.51007.

Keister, J., Johnson, T., Morgan, C., and Peterson, W. 2005. Biological indicators of the timing and direction of warm-water advection during the 1997/1998 El Niño off the central Oregon coast, USA. Mar. Ecol. Prog. Ser. 295: 43-48. doi:10.3354/meps295043

Lavaniegos, B.E., Jiménez-Herrera, M., and Ambriz-Arreola, I. 2019. Unusually low euphausiid biomass during the warm years of 2014-2016 in the transition zone of the California Current. Deep Sea Res. Part II Top. Stud. Oceanogr. 169-170: 104638. doi:10.1016/j.dsr2.2019.104638.

Lavaniegos, B.E., Jiménez-Pérez, L.C., and Gaxiola-Castro, G. 2002. Plankton response to El Niño 1997-1998 and La Niña 1999 in the southern region of the California Current. Prog. Oceanogr. 54(1-4): 33-58. doi:10.1016/ S0079-6611(02)00042-3.

Li, L., Mackas, D., Hunt, B., Schweigert, J., Pakhomov, E., Perry, R.I., et al. 2013. Zooplankton communities in the Strait of Georgia, British Columbia, track large-scale climate forcing over the Pacific Ocean. Prog. Oceanogr. 115: 90-102. doi:10.1016/j.pocean.2013.05.025.

Li, L., Keister, J.E., Essington, T.E., and Newton, J. 2019. Vertical distributions and abundances of life stages of the euphausiid Euphausia pacifica in relation to oxygen and temperature in a seasonally hypoxic fjord. J. Plankton Res. 41(2): 188-202. doi:10.1093/plankt/fbz009.

Lilly, L.E., and Ohman, M.D. 2018. CCE IV: El Niño-related zooplankton variability in the southern California Current System. Deep Sea Res. Part I Oceanogr. Res. Pap. 140: 36-51. doi:10.1016/j.dsr.2018.07.015.

Lindegren, M., Checkley, D.M., Jr., Koslow, J.A., Goericke, R., and Ohman, M.D. 2018. Climate-mediated changes in marine ecosystem regulation during El Niño. Global Change Biol. 24(2): 796-809. doi:10.1111/gcb.13993.

Liu, Y., Cobb, K.M., Song, H., Li, Q., Li, C.-Y., Nakatsuka, T., et al. 2017. Recent enhancement of central Pacific El Niño variability relative to last eight centuries. Nat. Commun. 8(1): 1-8. doi:10.1038/ncomms15386. PMID:28232747.

Lluch-Cota, D.B., Wooster, W.S., and Hare, S.R. 2001. Sea surface temperature variability in coastal areas of the northeastern Pacific related to the El Niño-Southern Oscillation and the Pacific Decadal Oscillation. Geophys. Res. Lett. 28(10): 2029-2032. doi:10.1029/2000GL012429.

Logerwell, E.A., Mantua, N., Lawson, P.W., Francis, R.C., and Agostini, V.N. 2003. Tracking environmental processes in the coastal zone for understanding and predicting Oregon coho (Oncorhynchus kisutch) marine survival. Fish. Oceanogr. 12(6): 554-568. doi:10.1046/j.1365-2419.2003.00238.x.

Lourie, S.A., and Vincent, A.C. 2004. Using biogeography to help set priorities in marine conservation. Conserv. Biol. 18(4): 1004-1020. doi:10.1111/ j.1523-1739.2004.00137.x.

Lynn, R.J., Bograd, S.J., Chereskin, T.K., and Huyer, A. 2003. Seasonal renewal of the California Current: The spring transition off California. J. Geophys. Res. 108(C8). doi:10.1029/2003JC001787.

Mackas, D.L., and Galbraith, M. 2002. Zooplankton community composition along the inner portion of Line P during the 1997-1998 El Nino event. Prog. Oceanogr. 54(1-4): 423-437. doi:10.1016/S0079-6611(02)00062-9.

Mackas, D.L., Kieser, R., Saunders, M., Yelland, D.R., Brown, R.M., and Moore, D.F. 1997. Aggregation of euphausiids and Pacific hake (Merluccius productus) along the outer continental shelf off Vancouver Island. Can. J. Fish. Aquat. Sci. 54(9): 2080-2096. doi:10.1139/f97-113.

Mackas, D.L., Thomson, R.E., and Galbraith, M. 2001. Changes in the zooplankton community of the British Columbia continental margin, 19851999, and their covariation with oceanographic conditions. Can. J. Fish. Aquat. Sci. 58(4): 685-702. doi:10.1139/f01-009.

Mackas, D., Galbraith, M., Faust, D., Masson, D., Young, K., Shaw, W., et al. 2013. Zooplankton time series from the Strait of Georgia: Results from 
year-round sampling at deep water locations, 1990-2010. Prog. Oceanogr. 115: 129-159. doi:10.1016/j.pocean.2013.05.019.

Mac Nally, R. 2000. Regression and model-building in conservation biology, biogeography and ecology: the distinction between - and reconciliation of - 'predictive' and 'explanatory' models. Biodivers. Conserv. 9(5): 655671. doi:10.1023/A:1008985925162.

Mac Nally, R. 2002. Multiple regression and inference in ecology and conservation biology: further comments on identifying important predictor variables. Biodivers. Conserv. 11(8): 1397-1401. doi:10.1023/A:1016250716679.

Manugian, S., Elliott, M.L., Bradley, R., Howar, J., Karnovsky, N., Saenz, B., et al. 2015. Spatial distribution and temporal patterns of Cassin's Auklet foraging and their euphausiid prey in a variable ocean environment. PLoS ONE, 10(12): e0144232. doi:10.1371/journal.pone.0144232. PMID:26629818.

Marinovic, B.B., Croll, D.A., Gong, N., Benson, S.R., and Chavez, F.P. 2002. Effects of the 1997-1999 El Niño and La Niña events on zooplankton abundance and euphausiid community composition within the Monterey Bay coastal upwelling system. Prog. Oceanogr. 54(1-4): 265-277. doi:10.1016/ S0079-6611(02)00053-8.

McGowan, J., Hines, E., Elliott, M., Howar, J., Dransfield, A., Nur, N., and Jahncke, J. 2013. Using seabird habitat modeling to inform marine spatial planning in central California's National Marine Sanctuaries. PLoS ONE, 8(8): e71406. doi:10.1371/journal.pone.0071406. PMID:23967206.

Nickels, C.F., Sala, L.M., and Ohman, M.D. 2018. The morphology of euphausiid mandibles used to assess selective predation by blue whales in the southern sector of the California Current System. J. Crustac. Biol. 38(5): 563-573. doi:10.1093/jcbiol/ruy062.

Nickels, C.F., Sala, L.M., and Ohman, M.D. 2019. The euphausiid prey field for blue whales around a steep bathymetric feature in the southern California current system. Limnol. Oceanogr. 64(1): 390-405. doi:10.1002/lno.11047.

Oliver, E.C., Donat, M.G., Burrows, M.T., Moore, P.J., Smale, D.A., Alexander, L.V., et al. 2018. Longer and more frequent marine heatwaves over the past century. Nat. Commun. 9(1): 1-12. doi:10.1038/s41467-018-03732-9. PMID:29636482.

Peterson, B., Emmett, R., Ralston, S., Forney, K.A., Road, S., and Cruz, S. 2006 The state of the California Current, 2005-2006: Warm in the north, cool in the south. Calif. Coop. Ocean. Fish. Investig. Rep. 47: 30-74.

Pittman, S.J., Connor, D.W., Radke, L., and Wright, D.J. 2011. Application of estuarine and coastal classifications in marine spatial management. In Treatise on estuarine and coastal science. Elsevier. pp. 163-205. doi:10.1016/ B978-0-12-374711-2.00110-8.

Qualls, K.M. 2019. Drivers of Euphausiid abundance and biomass in the Kitimat Fjord System, BC, Canada. M.S. thesis, Oregon State University.

Ralston, S., Field, J.C., and Sakuma, K.M. 2015. Long-term variation in a central California pelagic forage assemblage. J. Mar. Syst. 146: 26-37. doi:10.1016/j. jmarsys.2014.06.013.

Reiss, H., Cunze, S., König, K., Neumann, H., and Kröncke, I. 2011. Species distribution modelling of marine benthos: a North Sea case study. Mar. Ecol. Prog. Ser. 442: 71-86. doi:10.3354/meps09391.

Ressler, P.H., Brodeur, R.D., Peterson, W.T., Pierce, S.D., Vance, P.M., Røstad, A., and Barth, J.A. 2005. The spatial distribution of euphausiid aggregations in the Northern California Current during August 2000. Deep Sea Res. Part II Top. Stud. Oceanogr. 52(1-2): 89-108. doi:10.1016/j. dsr2.2004.09.032.

Robertson, R.R., and Bjorkstedt, E.P. 2020. Climate-driven variability in Euphausia pacifica size distributions off northern California. Prog. Oceanogr. 188: 102412. doi:10.1016/j.pocean.2020.102412.

Robinson, C.L.K. 1994. The influence of ocean climate on coastal plankton and fish production. Fish. Oceanogr. 3(3): 159-171. doi:10.1111/j.1365-2419.1994. tb00093.x.

Robinson, C.L.K. 2000. The consumption of euphausiids by the pelagic fish community off southwestern Vancouver Island, British Columbia. J. Plankton Res. 22(9): 1649-1662. doi:10.1093/plankt/22.9.1649.

Rockwood, R.C., Elliott, M.L., Saenz, B., Nur, N., and Jahncke, J. 2020. Modeling predator and prey hotspots: Management implications of baleen whale co-occurrence with krill in Central California. PLoS ONE, 15(7): e0235603. doi:10.1371/journal.pone.0235603. PMID:32634142.

Santora, J.A., Ralston, S., and Sydeman, W.J. 2011a. Spatial organization of krill and seabirds in the central California Current. ICES J. Mar. Sci. 68(7): 1391-1402. doi:10.1093/icesjms/fsr046.

Santora, J.A., Sydeman, W.J., Schroeder, I.D., Wells, B.K., and Field, J.C. $2011 b$. Mesoscale structure and oceanographic determinants of krill hotspots in the California Current: Implications for trophic transfer and conservation. Prog. Oceanogr. 91(4): 397-409. doi:10.1016/j.pocean.2011.04.002.
Santora, J.A., Field, J.C., Schroeder, I.D., Sakuma, K.M., Wells, B.K., and Sydeman, W.J. 2012a. Spatial ecology of krill, micronekton and top predators in the central California Current: Implications for defining ecologically important areas. Prog. Oceanogr. 106: 154-174. doi:10.1016/j.pocean.2012.08.005.

Santora, J.A., Sydeman, W.J., Schroeder, I.D., Reiss, C.S., Wells, B.K., Field, J.C., et al. 2012b. Krill space: a comparative assessment of mesoscale structuring in polar and temperate marine ecosystems. ICES J. Mar. Sci. 69(7): 1317-1327. doi:10.1093/icesjms/fss048.

Santora, J.A., Schroeder, I.D., Field, J.C., Wells, B.K., and Sydeman, W.J. 2014. Spatio-temporal dynamics of ocean conditions and forage taxa reveal regional structuring of seabird-prey relationships. Ecol. Appl. 24(7): 17301747. doi:10.1890/13-1605.1. PMID:29210234.

Santora, J.A., Zeno, R., Dorman, J.G., and Sydeman, W.J. 2018. Submarine canyons represent an essential habitat network for krill hotspots in a Large Marine Ecosystem. Sci. Rep. 8(1): 7579. doi:10.1038/s41598-018-25742-9. PMID:29765085.

Schroeder, I.D., Sydeman, W.J., Sarkar, N., Thompson, S.A., Bograd, S.J., and Schwing, F.B. 2009. Winter pre-conditioning of seabird phenology in the California Current. Mar. Ecol. Prog. Ser. 393: 211-223. doi:10.3354/meps08103.

Schroeder, I.D., Black, B.A., Sydeman, W.J., Bograd, S.J., Hazen, E.L., Santora, J.A., and Wells, B.K. 2013. The North Pacific High and wintertime pre-conditioning of California current productivity. Geophys. Res. Lett. 40(3): 541-546. doi:10.1002/grl.50100.

Schute, J.T., Boers, N., and Haigh, R. 2021. PBSmapping: mapping fisheries data and spatial analysis tools. R package version 2.73.0. Available from https:://CRAN.R-project.org/package=PBSmapping.

Shelton, A.O., Thorson, J.T., Ward, E.J., and Feist, B.E. 2014. Spatial semiparametric models improve estimates of species abundance and distribution. Can. J. Fish. Aquat. Sci. 71(11): 1655-1666. doi:10.1139/cjfas-2013-0508.

Siegel, V. 2000. Krill (Euphausiacea) life history and aspects of population dynamics. Can. J. Fish. Aquat. Sci. 57(S3): 130-150. doi:10.1139/f00-183.

Strub, P.T., Allen, J.S., Huyer, A., and Smith, R.L. 1987. Large-scale structure of the spring transition in the coastal ocean off western North America. J. Geophys. Res. 92(C2): 1527-1544. doi:10.1029/JC092iC02p01527.

Swartzman, G., Hickey, B., Kosro, P.M., and Wilson, C. 2005. Poleward and equatorward currents in the Pacific Eastern Boundary Current in summer 1995 and 1998 and their relationship to the distribution of euphausiids. Deep Sea Res. Part II Top. Stud. Oceanogr. 52(1-2): 73-88. doi:10.1016/j.dsr2.2004. 09.028 .

Sydeman, W.J., Santora, J.A., Thompson, S.A., Marinovic, B., and Lorenzo, E.D. 2013. Increasing variance in North Pacific climate relates to unprecedented ecosystem variability off California. Global Change Biol. 19(6): 1662-1675. doi:10.1111/gcb.12165.

Tanasichuk, R. 1998a. Interannual variations in the population biology and productivity of Euphausia pacifica in Barkley Sound, Canada, with special reference to the 1992 and 1993 warm ocean years. Mar. Ecol. Prog. Ser. 173: 163-180. doi:10.3354/meps173163.

Tanasichuk, R. 1998b. Interannual variations in the population biology and productivity of Thysanoessa spinifera in Barkley Sound, Canada, with special reference to the 1992 and 1993 warm ocean years. Mar. Ecol. Prog. Ser. 173: 181-195. doi:10.3354/meps173181.

Tanasichuk, R.W. 1999. Interannual variation in the availability and utilization of euphausiids as prey for Pacific hake (Merluccius productus) along the southwest coast of Vancouver Island. Fish. Oceanogr. 8(2): 150-156. doi:10.1046/ j.1365-2419.1999.00100.x.

Tanasichuk, R.W. 2002. Implications of interannual variability in euphausiid population biology for fish production along the south-west coast of Vancouver Island: a synthesis. Fish. Oceanogr. 11(1): 18-30. doi:10.1046/ j.1365-2419.2002.00185.x.

Thorson, J.T., Shelton, A.O., Ward, E.J., and Skaug, H.J. 2015. Geostatistical delta-generalized linear mixed models improve precision for estimated abundance indices for West Coast groundfishes. ICES J. Mar. Sci. 72(5): 1297-1310. doi:10.1093/icesjms/fsu243.

Ware, D.M., and Thomson, R.E. 2005. Bottom-up ecosystem trophic dynamics determine fish production in the Northeast Pacific. Science, 308(5726): 12801284. doi:10.1126/science.1109049.

Wells, B., Santora, J., Field, J., MacFarlane, R., Marinovic, B., and Sydeman, W. 2012. Population dynamics of Chinook salmon Oncorhynchus tshawytscha relative to prey availability in the central California coastal region. Mar. Ecol. Prog. Ser. 457: 125-137. doi:10.3354/meps09727.

Yamada, S.B., and Kosro, P.M. 2010. Linking ocean conditions to year class strength of the invasive European green crab, Carcinus maenas. Biol. Invasions, 12(6): 1791-1804. doi:10.1007/s10530-009-9589-y. 